\title{
Site-specific nitrogen management in winter wheat supported by low-altitude remote sensing and soil data
}

\author{
F. Argento ${ }^{1,2}$ (D) T. Anken ${ }^{2} \cdot$ F. Abt ${ }^{3} \cdot$ E. Vogelsanger ${ }^{1} \cdot$ A. Walter ${ }^{1} \cdot$ F. Liebisch $^{1,4}$ \\ Published online: 30 June 2020 \\ (c) The Author(s) 2020
}

\begin{abstract}
Site-specific nitrogen $(\mathrm{N})$ management in precision agriculture is used to improve nitrogen use efficiency (NUE) at the field scale. The objective of this study has been (i) to better understand the relationship between data derived from an unmanned aerial vehicle (UAV) platform and the crop temporal and spatial variability in small fields of about 2 ha, and (ii) to increase knowledge on how such data can support variable application of $\mathrm{N}$ fertilizer in winter wheat (Triticum aestivum). Multi-spectral images acquired with a commercially available UAV platform and soil available mineral $\mathrm{N}$ content (Nmin) sampled in the field were used to evaluate the in-field variability of the $\mathrm{N}$-status of the crop. A plot-based field experiment was designed to compare uniform standard rate (ST) to variable rate (VR) N application. Non-fertilized (NF) and N-rich (NR) plots were placed as positive and negative $\mathrm{N}$-status references and were used to calculate various indicators related to NUE. The crop was monitored throughout the season to support three split fertilizations. The data of two growing seasons (2017/2018 and 2018/2019) were used to validate the sensitivity of spectral vegetation indices (SVI) suitable for the sensor used in relation to biomass and $\mathrm{N}$-status traits. Grain yield was mostly in the expected range and inconsistently higher in VR compared to ST. In contrast, $\mathrm{N}$ fertilizer application was reduced in the VR treatments between 5 and $40 \%$ depending on the field heterogeneity. The study showed that the methods used provided a good base to implement variable rate fertilizer application in small to medium scale agricultural systems. In the majority of the case studies, NUE was improved around $10 \%$ by redistributing and reducing the amount of $\mathrm{N}$ fertilizer applied. However, the prediction of the $\mathrm{N}$-mineralisation in the soil and related $\mathrm{N}$-uptake by the plants remains to be better understood to further optimize in-season $\mathrm{N}$-fertilization.
\end{abstract}

Electronic supplementary material The online version of this article (https://doi.org/10.1007/s 1111 9-020-09733-3) contains supplementary material, which is available to authorized users.

\section{F. Argento}

francesco.argento@usys.ethz.ch

1 Institute of Agricultural Sciences, ETH Zürich, Universitätstrasse 2, 8092 Zurich, Switzerland

2 Digital Production, Agroscope, Tänikon 1, 8356 Ettenhausen, Switzerland

3 Swiss Future Farm, Education and Counselling Centre Arenenberg, 8268 Salenstein, Switzerland

4 Water Protection and Substance Flows, Agroscope, Reckenholzstrasse 191, 8046 Zurich, Switzerland 
Keywords Nitrogen management · Winter wheat · UAV · Variable rate application

\section{Abbreviations}

$\begin{array}{ll}\text { AFR } & \text { Apparent fertilizer recovery } \\ \text { AFR }_{\mathrm{g}} & \text { Apparent fertilizer recovery of grain } \\ \text { AFR }_{\text {tot }} & \text { Apparent fertilizer recovery of straw }+ \text { grain } \\ \text { CHF } & \text { Swiss francs } \\ \text { DAS } & \text { Days after sowing } \\ \text { DM } & \text { Dry matter } \\ \text { FOAG } & \text { Federal office of agriculture } \\ \text { FSO } & \text { Federal statistical office } \\ \text { G } & \text { Green band } \\ \text { GCP } & \text { Ground control point } \\ \text { GSD } & \text { Ground sampling distance } \\ \text { N } & \text { Nitrogen } \\ N_{\text {app }} & \text { Nitrogen application rate } \\ N_{c} & \text { Nitrogen concentration } \\ N_{\text {fert }} & \text { Nitrogen fertilizer } \\ \mathrm{N}_{\text {up }} & \text { Nitrogen uptake } \\ \text { NF } & \text { No fertilizer } \\ \text { NDRE } & \text { Normalized difference red-edge index } \\ \text { NDVI } & \text { Normalized difference vegetation index } \\ \text { NIR } & \text { Near-infrared band } \\ \text { NNI } & \text { Nitrogen nutrition index } \\ \text { NR } & \text { Nitrogen rich } \\ \text { NUE } & \text { Nitrogen use efficiency } \\ \text { MCARI } & \text { Modified chlorophyll absorption ratio index } \\ \text { MTVI2 } & \text { Modified triangular vegetation index 2 } \\ \text { PFP } & \text { Partial factor productivity } \\ \text { PRIF } & \text { Principles of fertilization of agricultural crops in Switzerland } \\ \text { R } & \text { Red band } \\ \text { R }^{2} & \text { Coefficient of determination } \\ \text { RE } & \text { Red-edge band } \\ \text { RMSE } & \text { Root mean square error } \\ \text { SFF } & \text { Swiss future farm } \\ \text { ST } & \text { Standard } \\ \text { SVI } & \text { Spectral vegetation indices } \\ \text { TGW } & \text { Thousand-grain weight } \\ \text { UAV } & \text { Unmanned aerial vehicle } \\ \text { VR } & \text { Variable Rate } \\ \text { WRB } & \text { World reference base soil classification system } \\ & \end{array}$

\section{Introduction}

In Swiss agriculture, farm size is considered medium to small scale averaging around 20 ha (Swiss Federal Statistical Office FSO 2019). The scale is comparable to other small scale farming systems in the EU-28 countries, in which $85 \%$ of the farms have a size between 0.1 
and 20 ha (EUROSTAT 2016), and partly to village farm systems in the North China Plain (Chen et al. 2019; Zha et al. 2019) composed of family households managing 0.3-0.5 ha. At this scale, monitoring and management of in-field variability are confronted with additional obstacles compared to large-scale precision farming operations. Specifically, farmers have a lower level of specialization and smaller investment potential. In Switzerland, the fertilizer recommendation is usually based on the "Principles of fertilization of agricultural crops in Switzerland" (PRIF) (Sinaj and Richner 2017). The PRIF recommends a total N fertilizer amount given a certain yield expectation and other soil and agronomic factors and is based on a broad long-term dataset with replicates all over Switzerland. For winter wheat, the recommendation ideally includes an initial soil $\mathrm{N}_{\min }$ test to account for available soil $\mathrm{N}$ and it recommends up to three split applications at key stages of crop development. Splitting the application has the advantage of reducing the risk of $\mathrm{N}$ loss by emission (Hunt et al. 2019) and providing better availability of $\mathrm{N}$ with a view to increased crop growth and grain quality. Nonetheless, $\mathrm{N}$ fertilizers are widely used and their improper application represents both an environmental risk and a cost factor (Jan et al. 2017; Spiess 2011). Therefore, precise fertilization is a key challenge for producers who need to manage their crop production systems in order to minimize $\mathrm{N}$ losses to air or water, while achieving high crop yields of good quality (Zebarth et al. 2009). In fact, the inaccurate calculation of fertilizer requirements is often the main cause of environmental problems such as eutrophication or pollution of water bodies and emission of the potent greenhouse gas $\mathrm{N}_{2} \mathrm{O}$ and thus for additional societal costs (Lassaletta et al. 2014). It is, therefore, of practical and political concern to increase nitrogen use efficiency (NUE) and reduce high $\mathrm{N}$ input in the agricultural sector. In 2014, the efficiency of N used in Swiss agriculture was around 30\% (FSO 2019), which is lower compared to the Danish agriculture, for instance, depicting a NUE of $41 \%$ in 2012 (Hansen et al. 2017).

Fertilizers are still typically distributed in a uniform way across fields without considering in-field variability in Switzerland. This is also true for the majority of wheat production, which is the most abundant crop in Switzerland. However, the spatial and temporal distribution of available $\mathrm{N}$ for agricultural crops in the field varies greatly according to a multitude of factors including soil properties, climate and soil management (Kindred et al. 2015), which influence $\mathrm{N}$ supply, mineralization processes, plant response to $\mathrm{N}$ and subsequently growth, yield and quality (Samborski et al. 2009). Minimized or site-specific application of fertilizers in precision agriculture systems has the potential to mitigate leaching problems as well as the emission of greenhouse gases (Walter et al. 2017). In fact, it was shown that site-specific fertilization can increase the NUE at field scale (Basso et al. 2016; Cohan et al. 2018; Raun et al. 2002) which was recently confirmed for small to medium scale agriculture systems (Van Loon et al. 2018; Wang et al. 2019) similar to Swiss agriculture. Therefore, variable rate $\mathrm{N}$ fertilization has the potential to improve NUE in small to large-scale agricultural cropping systems (Diacono et al. 2013; Ebertseder et al. 2003; Ravier et al. 2018). Yet, previous studies have mostly taken fields of large size into account; in practice, small-scale heterogeneities within fields smaller than one ha are typically neglected.

At present, remote, aerial and ground based sensing techniques emerge as a key element for observation of in-field variability. A combination of remote and proximal sensing techniques will enable a better understanding of cropping systems, from mineralization dynamics in soils to crop growth and nutrient uptake (Gabriel et al. 2017; Khan et al. 2018; Nawar et al. 2017). The use of spectral information to detect changes in canopy structure and growth is a well-established technology for a multitude of platforms (Matese et al. 2015; Muñoz-Huerta et al. 2013; Walter et al. 2018). For N-status detection of plants, different 
paths have been explored in basic research e.g. hyper- and multi-spectral image spectroscopy, which delivers responses as spectral vegetation indices (SVI), and radiative transfer models (Féret et al. 2020). Recently, it has been suggested that the relation to proteins is more consistent than the previously assumed relation to chlorophyll (Berger et al. 2020). When applying this knowledge in practical field management, many studies have made use of SVI calculated from the near-infrared (NIR) region of the light spectrum (790-840 $\mathrm{nm}$ ) and surrounding wavelengths, as for example the red-edge (RE) region located around 730 $\mathrm{nm}$. This region appears to have a consistent direct relationship with the biomass and $\mathrm{N}$ status of the crop - a relation shown to exist for many crops including wheat, maize and sugar beet (Cammarano et al. 2011; Li et al. 2014; Liebisch et al. 2014; Prey and Schmidhalter 2019). However, it has been suggested that reflectance in the RE region, which is higher than that in the red region and which is relatively constant throughout the vegetative season, is not more sensitive to $\mathrm{N}$ per se (Bean et al. 2018). Instead, indices that make use of the RE band seem to enhance the importance of the NIR reflectance. Because such spectral signals can be assessed with commercially available sensors and because SVI derived from them appear to capture the crop in-field variability in a consistent way, such SVI are typically used to display in-field variability maps for crop $\mathrm{N}$-status.

Unmanned aerial vehicles (UAV) are platforms suitable for monitoring fields of small to medium size. Main advantages of these systems are their flexibility of use and their capability to deliver high spatial and temporal resolution of observations simultaneously. Main disadvantages are the initial financial and knowledge related investments and the time needed to acquire and process the remote sensing data (Hunt and Daughtry 2018). On the market, a broad selection of sensors and platforms is available (Aasen et al. 2018) and the quality of the obtainable data has reached levels which support precision fertilization methodologies. Still, the quantification of crop N-status and subsequent fertilization support based on remote sensing imagery is not fully standardized. Calibration with ground data usually improves the reliability of derived fertilizer application maps. However, it is still difficult to generalize the relationship of the sensed values to the crop $\mathrm{N}$ demand for seasons (temporal), regions (spatially) and different crop species or genotypes of the same species.

The objectives of this study were (i) to better understand the relationship between data derived from a UAV platform representing temporal and spatial variability of crops in small fields of about 2 ha, and (ii) to increase knowledge on how such data can support variable application of $\mathrm{N}$ fertilizer in winter wheat (Triticum aestivum). Four fields in total were treated as four case studies to show how the variability between and within fields influences the outcome of site-specific fertilization. The main hypothesis was that the implementation of site-specific $\mathrm{N}$ fertilization using VRA techniques would reduce average $\mathrm{N}$ application compared to the standard fertilization strategy without affecting yield and thus increasing NUE.

\section{Materials and methods}

\section{Experimental fields and design}

The experimental fields are located at the "Swiss Future Farm" in Tänikon, Switzerland $\left(47.4790021^{\circ} \mathrm{N}, 8.9059287^{\circ} \mathrm{E}\right)$. The farm is a concept to test and show innovative agricultural technologies, operated by the three partners AGCO (Duluth, USA), GVS Agrar 
(Herblingen, Switzerland) and the cantonal education and extension service (Arenenberg, Switzerland). The climate in this region is characterized by $1170 \mathrm{~mm}$ annual rainfall and an average annual temperature of $8.6^{\circ} \mathrm{C}(1970-2018)$ recorded by a local weather station from the federal office of meteorology (MeteoSwiss). In the growing season 2017/2018, the first experiment was carried out in field F1, while in the growing season 2018/2019 the fields F2, F3 and F4 were used (Fig. 1).

The soil types of the four investigated fields (F1-4) were classified during a soil survey in 1977, provided by the national soil-monitoring network (NABODAT 2019). According to the world reference base for soils (WRB, Food and Agriculture Organization FAO 2014), the soil of F1 is characterized as a Gleysol, with a more stagnating Gleysol zone richer in organic matter in the central part. F2 is characterized as a Cambisol, whereas F3 is mainly characterized as a Luvisol and in F4 two main soil types, a Gleysol (to the west) and an Alisol (to the east) are present. The heterogeneity of soil properties was high between and within the fields. Among fields, the clay content varied between 25 and $35 \%$ and the content of $\mathrm{C}_{\text {org }}$ fraction calculated from organic matter content $(\mathrm{OM})$ ranged between 1.5 and $3.0 \%$ (Table 1). Within fields, the standard deviation of clay was between 7 and $9 \%$ in all four fields while F1 and F4 showed a higher standard deviation (0.6-0.9\%) compared to F2 and F3. The fields were sown with winter wheat (T. aestivum) of the same cultivar (Arnold, Saatzucht Donau, Austria) and covered an area of two ha on average (Table 1). Whereas wheat followed maize in the crop rotation in F1-3, sown on the 19th of October in 2017 and 9th and 12th of October 2018, respectively, F4 followed 2 years of temporal grassland and was sown 1 month later on 5th of November 2018. For F1 a randomized block design with three N- fertilization treatments: standard (ST), variable rate (VR) and non-fertilized $(\mathrm{NF})$, replicated in six blocks each $(n=6)$ was established. The dimension of a single plot was $15 \times 50 \mathrm{~m}$, to match the operational range of the used pneumatic fertilizer spreader (Rauch Aero 2215, Sinsheim, Germany). The N-fertilization treatments are described in detail in the section below (Fertilization and Variable Rate method). For the second year, a non-randomized block design with two treatments ST and VR replicated in three fields F2, F3 and F4 $(n=7)$ plus two reference treatments NF and N-rich (NR) differing in number and distribution in the fields were established with regard to fit the different soil zones

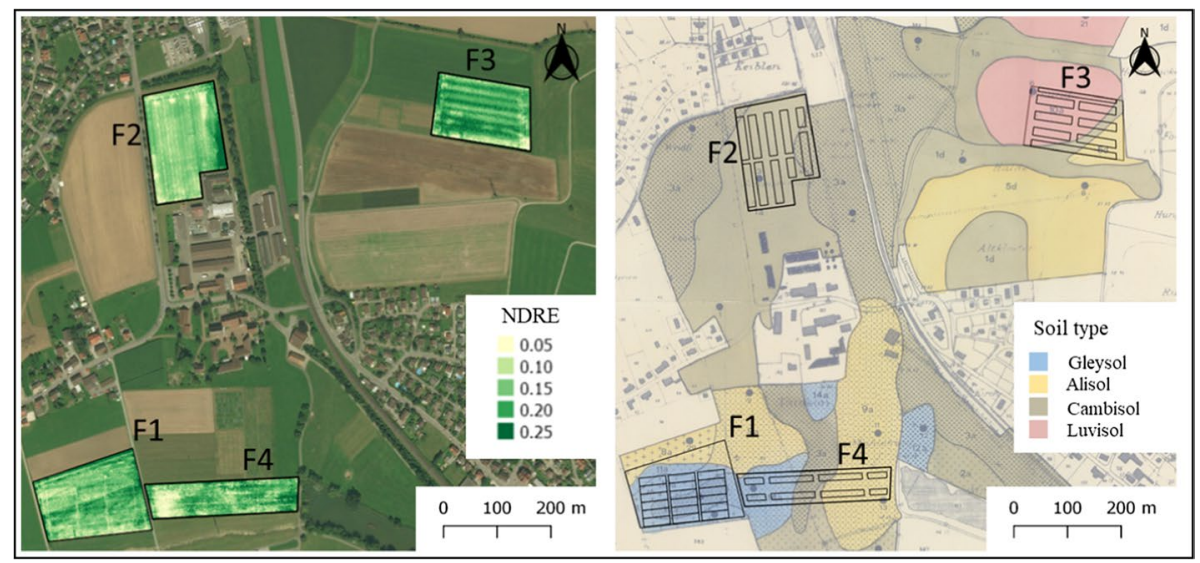

Fig. 1 Experimental fields F1 (2018), F2, F3 and F4 (2019) depicting crop variability (false-colour field maps by normalized difference red-edge index NDRE at the end of April, left) and soil type variability (right) with the sampling plot overlay (Color figure online) 
Table 1 Soil and field properties for the four experimental fields F1 (2018) and F2-F4 (2019)

\begin{tabular}{lllll}
\hline Field properties & F1 & F2 & F3 & F4 \\
\hline Area (ha) & 2.2 & 2.5 & 1.9 & 1.6 \\
Previous crop & Maize & Maize & Maize & Temporal grassland \\
Sowing date & 19.10 .2017 & 9.10 .2018 & 12.10 .2018 & 5.11 .2018 \\
$\mathrm{pH}$ & $7.7 \pm 0.1$ & $6.9 \pm 0.4$ & $6.9 \pm 0.4$ & $7.5 \pm 0.2$ \\
Carbonate test ${ }^{\mathrm{a}}$ & + & - & \pm & + \\
$\mathrm{C}_{\text {org }}(\%)^{\mathrm{b}}$ & $3.2 \pm 0.9$ & $2.4 \pm 0.1$ & $1.5 \pm 0.3$ & $2.8 \pm 0.6$ \\
$\mathrm{P}\left(\mathrm{mg} \mathrm{kg}^{-1}\right)^{\mathrm{c}}$ & $1.9 \pm 0.6$ & $1.3 \pm 0.5$ & $2.7 \pm 1.1$ & $1.3 \pm 0.46$ \\
$\mathrm{~K}\left(\mathrm{mg} \mathrm{kg}^{-1}\right)^{\mathrm{c}}$ & $38.5 \pm 14$ & $17.9 \pm 5.8$ & $32.6 \pm 9.5$ & $18.7 \pm 6.4$ \\
$\mathrm{Mg}\left(\mathrm{mg} \mathrm{kg}^{-1}\right)^{\mathrm{c}}$ & $381.7 \pm 77.1$ & $377.0 \pm 43.1$ & $172.5 \pm 71.7$ & $282.3 \pm 123.4$ \\
Clay $(\%)$ & $24.5 \pm 4.1$ & $34.6 \pm 7.3$ & $25.9 \pm 9.1$ & $35.0 \pm 9.5$ \\
Silt $(\%)$ & $37.5 \pm 2.5$ & $39.1 \pm 1.5$ & $38.4 \pm 3.1$ & $34.1 \pm 2.4$ \\
Sand $(\%)$ & $37.9 \pm 5.1$ & $26.3 \pm 6.9$ & $35.6 \pm 8.9$ & $30.9 \pm 9.3$ \\
Soil Type $(\mathrm{WRB})^{\mathrm{d}}$ & Gleysol & Cambisol & Luvisol and Alisol & Gleysol and Alisol \\
\hline
\end{tabular}

For average values reported: $\mathrm{n}=6$

${ }^{\mathrm{a}} \mathrm{CO}_{2}$ release reaction to hydrochloric acid (+) indicates the presence of carbonate

${ }^{\mathrm{b}} \mathrm{C}_{\text {org }}=\mathrm{OM} / 1.724$ (Howard 1965)

${ }^{\mathrm{c}}$ Plant available- $\mathrm{P}, \mathrm{K}$ extraction with $\mathrm{CO}_{2}$ saturated $\mathrm{H}_{2} \mathrm{O} / \mathrm{Mg}: \mathrm{CaCl}_{2}$ extraction (ÖLN 2018)

${ }^{\mathrm{d}}$ World reference database for soils (FAO 2014)

identified before the season. The dimension of a single plot was $15 \times 90 \mathrm{~m}$, which was chosen to match the operational range of the disc spreader (Sulky X40+ECONOV, SulkyBurel, Châteaubourg, France) that was mounted on the cultivation tractor (Massey Ferguson S 5713, AGCO, Duluth, USA). The tractor was equipped with a Valtra Smart Touch terminal (Valtra Inc., Suolahti, Finland), featured with "Vario Doc Pro" software (Application Status: 2.2.2, BSP: nt03_171212_134701, Kernel: 3.0.35, Based on Revision: 26565, Built on Machine: nt0x-vm, AGCO, Duluth, USA).

The fields were managed without the use of chemical plant protection and growth regulators. Mechanical weeding by means of a tined harrow (Treffler TS1520HM3) was carried out in early spring. Fertilizer was applied in the form of mineral ammonium nitrate (Agroline-Landor Fenaco, Muttenz, Switzerland, composition: $24 \% \mathrm{~N}, 5 \% \mathrm{Mg}$ and $8.5 \% \mathrm{~S}$ ). No additional $\mathrm{P}$ and $\mathrm{K}$ were fertilized. The fields were harvested using a combine harvester (Fendt 5275 C PLI, AGCO, Duluth, USA).

\section{Remote sensing of the crop}

The low-altitude remote sensing UAV platform was composed of a multispectral camera "Parrot Sequoia" (Parrot, Paris, France) mounted on a quadcopter "P4P" (DJI, Shenzhen, China) flown over the field on a weekly to bi-weekly basis. Spectral information of the crop was recorded in four bands of the light spectrum, namely green $(\mathrm{G})$ centred at $550 \pm 40$ $\mathrm{nm}$, red $(\mathrm{R})$ at $660 \pm 40 \mathrm{~nm}$, red-edge $(\mathrm{RE})$ at $735 \pm 10 \mathrm{~nm}$ and near-infrared (NIR) at $790 \pm 40 \mathrm{~nm}$. The output of the camera consisted of one separate image for each band. The images were captured while the camera was flown over the field in a single grid automatic flight plan generated by the software Pix4D Capture (Pix4D, Lausanne, Switzerland) by 
the drone at $5 \mathrm{~m} \mathrm{~s}^{-1}$ speed and $1.9 \mathrm{~s}$ time interval between the single images at 50-80 $\mathrm{m}$ height. The optimal flight parameters were calculated with the help of the PhenoFly Planning Tool (Roth et al. 2018). The ground sampling distance (GSD) of the singleband images was between 4.5 and $8.4 \mathrm{~cm} \mathrm{pixel}^{-1}$ depending on flight altitude. The raw images were processed in the photogrammetry software Pix4D Mapper (Pix4D, Lausanne, Switzerland, version 4.5). First, a radiometric correction was applied by using an Airinov reflectance target (Parrot Airinov, Paris, France), then the images were transformed to an orthomosaic to create a reflectance map and finally, they were georeferenced using ground control points (GCP). GCPs were annually established within and around each field before generating final index maps of the field. The normalized difference red-edge index (NDRE $=(\mathrm{NIR}-\mathrm{RE}) /(\mathrm{NIR}+\mathrm{RE})$; Barnes et al. 2000) was selected as N-status indicator. This spectral vegetation index has been chosen as it showed consistent relationship with $\mathrm{N}$ uptake of the plants (Argento et al. 2019; Basso et al. 2016; Li et al. 2018). Additionally, the normalized difference vegetation index $(\mathrm{NDVI}=(\mathrm{NIR}-\mathrm{R}) /(\mathrm{NIR}+\mathrm{R})$; Rouse et al. 1974) was calculated, because it correlates closely to canopy cover and biomass (Liebisch et al. 2017; Tucker 1979; Tucker et al. 1980) and is therefore often used to provide decision support for variable rate $\mathrm{N}$ fertilization (Tremblay et al. 2009; Walsh et al. 2013).

Other indices reported in the manuscript include the green NDVI [GNDVI $=(\mathrm{NIR}-\mathrm{G}) /$ $(\mathrm{NIR}+\mathrm{G}]$, Buschmann and Nagel 1993), the modified triangular vegetation index 2 $\left(\mathrm{MTVI} 2=1.5^{*}\left(2.5^{*}(\mathrm{NIR}-\mathrm{R})-1.3 *(\mathrm{NIR}-\mathrm{G})\right) /\left((2 * \mathrm{NIR}+1)^{2}-\left(6^{*} \mathrm{NIR}-5^{*} \mathrm{R}^{0.5-0.5}\right)\right)^{0.5}\right)$ and the modified chlorophyll absorption in reflectance index [MCARI $=((\mathrm{RE}-\mathrm{R})-$ $\left.0.2 *(\mathrm{RE}-\mathrm{G}))^{*}(\mathrm{RE} / \mathrm{R})\right)$; Haboudane et al. 2004]. The latter two are also used as a combined index MCARI/MTVI2 (Eitel et al. 2007).

\section{Soil and plant analysis}

In both seasons, soil samples were collected in each field in early spring from six sampling locations based on the soil type mapping (approximately three sampling locations/ha). For each sampling location, six to eight soil cores were taken and mixed separately for the three depths $0-30 \mathrm{~cm}, 30-60 \mathrm{~cm}$ and $60-90 \mathrm{~cm}$, respectively. Out of these samples $\mathrm{N}_{\text {min }}$ available in the soil (Table 2) was measured as $\mathrm{NH}_{4}$ (ammonium test) and $\mathrm{NO}_{3}$ (Aluminium-sulphate extraction combined with a nitrate electrode) and converted in $\mathrm{kg} \mathrm{N} \mathrm{ha}^{-1}$ using the reference method by the federal agriculture research centre (Agroscope 1995). For the depth of 0-20 cm, phosphorus $(\mathrm{P})$, potassium $(\mathrm{K})$ and magnesium $(\mathrm{Mg})$ content, organic carbon $\left(\mathrm{C}_{\mathrm{org}}\right)$, texture, $\mathrm{pH}$ and carbonate content were measured additionally, following the guidelines for the mandatory soil samples that farmers perform to be eligible for direct payments (ÖLN, 2018).

Plant biomass samples were collected at various growth stages during the season and the respective growth stages were recorded using the $\mathrm{BBCH}$ decimal scale (Meier et al. 2009). In the first year, the samples were collected two times at BBCH 32 (second knot) and at $\mathrm{BBCH} 84$ shortly before harvest in two subsamples per plot each covering an area of $50 \times 60 \mathrm{~cm}$ (four rows at $15 \mathrm{~cm}$ spacing) for a total of 36 samples. The BBCH 32 samples were dried at $60{ }^{\circ} \mathrm{C}$ for $48 \mathrm{~h}$ to quantify dry matter (DM) and afterwards $\mathrm{N}$ concentration $\left(\mathrm{N}_{\mathrm{c}}\right)$ was measured with a Flash EA 1112 Series elemental analyser (Thermo Italy, Rodano, Italy) coupled to a Finnigan MAT Delta ${ }^{\text {plus } X P}$ isotope ratio mass spectrometer (Finnigan MAT, Bremen, Germany). The samples at harvest (BBCH 84) were collected in two subsamples per plot as described for BBCH 32 above. Plants were cut at $10 \mathrm{~cm}$ over the soil and air-dried for 2 weeks. The grains were mechanically separated from the straw to differentiate 
Table 2 Available $\mathrm{N}_{\min }(\mathrm{kg} \mathrm{N}$ $\mathrm{ha}^{-1}$ ) per sampling location with mean $(n=6)$ and standard deviation from three different depths $(0-30,30-60,60-90 \mathrm{~cm})$ for the four fields $(\mathrm{F} 1-4)$

\begin{tabular}{|c|c|c|c|c|c|c|c|c|c|}
\hline \multirow[t]{2}{*}{ Field } & \multirow[t]{2}{*}{ Depth $(\mathrm{cm})$} & \multicolumn{8}{|c|}{$\operatorname{Nmin}\left(\mathrm{kg} \mathrm{N} \mathrm{ha}^{-1}\right)$} \\
\hline & & 1 & 2 & 3 & 4 & 5 & 6 & Mean & SD \\
\hline \multirow[t]{3}{*}{$\mathrm{F} 1$} & $0-30$ & 14 & 17 & 24 & 22 & 25 & 21 & 20 & 4 \\
\hline & $30-60$ & 9 & 11 & 15 & 13 & 24 & 12 & 14 & 5 \\
\hline & $60-90$ & 10 & 8 & 9 & 11 & 18 & 8 & 11 & 3 \\
\hline Total & $0-90$ & 33 & 37 & 48 & 46 & 66 & 41 & 45 & 11 \\
\hline \multirow[t]{3}{*}{$\mathrm{F} 2$} & $0-30$ & 15 & 14 & 16 & 12 & 19 & 18 & 16 & 2 \\
\hline & $30-60$ & 14 & 10 & 9 & 10 & 9 & 10 & 10 & 2 \\
\hline & $60-90$ & 24 & 9 & 7 & 11 & 6 & 7 & 11 & 6 \\
\hline Total & 0-90 & 53 & 33 & 31 & 32 & 34 & 35 & 36 & 8 \\
\hline \multirow[t]{3}{*}{ F3 } & $0-30$ & 7 & 11 & 5 & 6 & 6 & 11 & 8 & 2 \\
\hline & $30-60$ & 5 & 8 & 3 & 5 & 4 & 5 & 5 & 2 \\
\hline & $60-90$ & 7 & 6 & 6 & 8 & 7 & 4 & 6 & 1 \\
\hline Total & $0-90$ & 19 & 25 & 14 & 19 & 17 & 20 & 19 & 3 \\
\hline \multirow[t]{3}{*}{$\mathrm{F} 4$} & $0-30$ & 20 & 24 & 21 & 25 & 23 & 28 & 24 & 3 \\
\hline & $30-60$ & 14 & 26 & 15 & 15 & 20 & 29 & 20 & 6 \\
\hline & $60-90$ & 10 & 14 & 9 & 11 & 18 & 21 & 14 & 4 \\
\hline Total & $0-90$ & 44 & 64 & 45 & 51 & 61 & 78 & 57 & 12 \\
\hline
\end{tabular}

between weights of grains and straw that together make up the plant dry weight. $\mathrm{N}$ concentration was measured in both the milled grains and straw at $7 \%$ water content. In the second year, biomass samples were collected four times at BBCH 25 (end of tillering), BBCH 31 (beginning of stem elongation), BBCH 39 (flag leaf) and BBCH 84 (pre-harvest, 15th July 2019). From each plot, three subsamples were collected, each covering an area of $50 \times 60$ $\mathrm{cm}$ (four rows at $15 \mathrm{~cm}$ spacing), for a total of 72 sampling locations across three fields. The samples were treated and analysed as described above for the previous season. From a subsample of the grains, one thousand grains were counted with a seed counter (Contador, Pfeuffer GmbH, Kitzingen, Germany) and weighed to determine the thousand-grain weight (TGW, g). Another subsample of the grains was used to determine the protein content (GVS Agrar AG, Herblingen, Switzerland). To investigate wheat $\mathrm{N}$ status, three plant traits i.e. $\mathrm{N}$ concentration $\left(\mathrm{N}_{\mathrm{c}}\right)$, total $\mathrm{N}$ in the aboveground biomass $\left(\mathrm{N}_{\mathrm{up}}\right.$, Eq. 1) and the nitrogen nutrition index (NNI, Eq. 2) were chosen. These indicators are often used to assess or calibrate crop $\mathrm{N}$ fertilizer demand. The $\mathrm{N}$ uptake $\left(\mathrm{N}_{\text {up }}, \mathrm{kg} \mathrm{N} \mathrm{ha}^{-1}\right)$ was calculated by multiplying the dry matter biomass (DM, $\mathrm{kg} \mathrm{ha}^{-1}$ ) with the corresponding $\mathrm{N}_{\mathrm{c}}(\%)$ of the plant sample:

$$
N_{u p}=D M * N_{c}
$$

The NNI is an index based on the principle that $\mathrm{N}_{\mathrm{c}}$ decreases with growing biomass. The experimental dilution curve reflecting the relationship between DM and $\mathrm{N}_{\mathrm{c}}$ values can be used to relate the measured $\mathrm{N}_{\mathrm{c}}$ to a critical $\mathrm{N}_{\text {crit }}$ i.e. the lowest $\mathrm{N}_{\mathrm{c}}$ necessary to obtain maximum biomass at a given growth stage (Justes et al. 1994; Prost and Jeuffroy 2007). NNI values $<1$ indicate an $\mathrm{N}$ deficiency while NNI values $>1$ indicate an $\mathrm{N}$ surplus.

$$
N N I=N_{c} /\left(5.35 * D M^{(-0.442)}\right)
$$




\section{Fertilization and variable rate method}

The selected fertilization strategy is based on the $\mathrm{N}_{\text {min }}$ method suggested in the PRIF (Sinaj and Richner 2017) as well as the standard application of the farm manager at the experimental site. Based on the recommendations, N-fertilization was divided in three split applications targeting the growth stages: end of tillering, beginning of stem elongation and flag leaf, respectively. On the field F1, the mean $0-90 \mathrm{~cm} \mathrm{~N}_{\min }$ was used as a reference for the calculation of the first split application to be applied as shown in Table 3. For the ST treatment, an average field $\mathrm{N}_{\min }$ value was used as farmers usually do. For the VR, the specific $\mathrm{N}_{\min }$ of each plot was subtracted from the total. According to this procedure, e.g. plot 2 with $\mathrm{N}_{\min }=30 \mathrm{~kg} \mathrm{~N} \mathrm{ha}^{-1}$ received $80-30=50 \mathrm{~kg} \mathrm{~N} \mathrm{ha}^{-1}$ fertilizer with the first split. For the second and third split, the values were qualitatively adjusted based on the NDRE index map produced few days before the fertilization. That means e.g. plot 10 with NDRE mean value of 0.25 (20\% higher than the field average) received $20 \%$ less fertilizer i.e. $40 \mathrm{~kg} \mathrm{~N} \mathrm{ha}^{-1}$ in the second split.

In the second year, a different approach was selected. The mean 0-30 $\mathrm{cm} \mathrm{N}_{\min }$, considered more relevant for the initial phase of plant growth, was used as a reference for the calculation of the first split application for VR only, as shown in Table 3. The ST in this season was based on the farm managers' standard application (hence without applying $\mathrm{N}_{\min }$ correction). For the VR treatment, the $\mathrm{N}_{\min }$ values from the six locations were interpolated to create an $\mathrm{N}_{\min }$ map of the field. The fields were then divided in $N_{\text {min }}$ management zones (Mattei et al. 2020) and for each VR plot, the corresponding $\mathrm{N}_{\text {min }}$ value was used to adjust the first split. For example plot 2 of field F2 was in between two zones with 18 and $24 \mathrm{~kg} \mathrm{~N} \mathrm{ha}^{-1}$, respectively, therefore it received two variable applications of $80-18=62 \mathrm{~kg} \mathrm{~N} \mathrm{ha}^{-1}$ and $80-24=56 \mathrm{~kg} \mathrm{~N} \mathrm{ha}^{-1}$ in the first split. The second and third split applications were adjusted based on an application map produced by applying Eq. 3, experimentally derived from the first season, to an NDRE index map produced few days before fertilization. For the optimization of the second and third fertilization split in the VR treatment, the NDRE values were used to adjust the standard amount of fertilization $\left(\mathrm{N}_{\mathrm{ST}}, \mathrm{kg} \mathrm{N} \mathrm{ha}^{-1}\right)$. Assuming that higher reflectance intensity corresponds to a better plant $\mathrm{N}$ status, $\mathrm{N}$ fertilizer $\left(\mathrm{N}_{\text {fert, }}, \mathrm{kg} \mathrm{N} \mathrm{ha}^{-1}\right)$ values for $\mathrm{VR}$ were calculated by applying Eq. 3 to each pixel.

$$
N_{f e r t, i}=N_{S T}-N_{c o r r, i}
$$

Table 3 Applied amount and distribution of $\mathrm{N}$-fertilizer $\left(\mathrm{kg} \mathrm{N} \mathrm{ha}^{-1}\right)$. For VR, the range of applied amounts per plot is shown

\begin{tabular}{|c|c|c|c|c|c|}
\hline Field & Treatment & Split 1 & Split 2 & Split 3 & Total \\
\hline & & BBCH 23 & ВBCH 32 & BBCH 45 & \\
\hline \multirow[t]{4}{*}{$\mathrm{F} 1$} & ST & $80-\mathrm{N}_{\min }=36$ & 60 & 20 & 116 \\
\hline & VR & $80-\mathrm{N}_{\min }=0$ to 50 & 40 to 70 & 0 to 20 & 50 to 132 \\
\hline & $\mathrm{NF}$ & - & - & - & 0 \\
\hline & & BBCH 25 & ВBCH 31 & ВBCH 39 & \\
\hline \multirow[t]{4}{*}{ F2-4 } & ST & 70 & 60 & 25 & 155 \\
\hline & VR & $80-\mathrm{N}_{\min }=52$ to 75 & 40 to 70 & 10 to 30 & 95 to 149 \\
\hline & $\mathrm{NF}$ & - & - & - & 0 \\
\hline & NR & 100 & 60 & - & 160 \\
\hline
\end{tabular}


The correction factor at pixel $i$ in the field $\left(\mathrm{N}_{\text {corr, }}, \mathrm{kg} \mathrm{N} \mathrm{ha}^{-1}\right)$ was calculated as in Eq. 4 by adjusting the $\mathrm{N}_{\mathrm{ST}}$ according to the relative difference of reflectance intensity at a point $i$ $\left(\mathrm{x}_{\mathrm{i}}\right)$ and the mean of the reflectance intensity over the whole field $\left(\mathrm{x}_{\mathrm{m}}\right)$.

$$
N_{c o r r, i}=N_{S T} * \frac{x_{i}-x_{m}}{x_{m}}
$$

The fertilizer was spread in variable amounts over the field, according to the final prescription map, which was created using the software (NEXT Farming AG Office, version 1.8.1.14, Pfarrkirchen, Germany) and uploaded via the Vario Doc Server onto the tractor terminal.

\section{Evaluation of $\mathrm{N}$ use efficiency}

The NUE was evaluated by means of three different indicators: the apparent fertilizer recovery (AFR) (Kindred et al. 2015), also known as recovery efficiency, was used to quantify the $\mathrm{N}$ fertilizer recovered by the crop (Eq. 5). Therefore, $\mathrm{N}_{\text {up }}$ from the NF plot (as a measure of the soil $\mathrm{N}$ supply) was subtracted from the $\mathrm{N}$ uptake of a treatment plot (VR, ST, or NR) and divided for the N fertilizer applied. AFR was calculated for both the total $\mathrm{N}_{\text {up }}$ (AFR tot) and for the $\mathrm{N}_{\text {up }}$ in the grains (AFR grain).

$$
\operatorname{AFR}(\%)=\frac{N_{u p}-N_{u p}(N F)}{N_{a p p}} * 100
$$

The partial factor productivity (PFP) was calculated according to Wang et al. (2019) as a measure of the relationship between the grain yield in a fertilized plot $\left(\mathrm{Y}_{\text {fert }}, \mathrm{kg} \mathrm{ha}^{-1}\right)$ and the $\mathrm{N}$ applied in that plot $\left(\mathrm{kg} \mathrm{N} \mathrm{ha}^{-1}\right)$ in Eq. 6 .

$$
P F P=\frac{Y_{f e r t}}{N_{a p p}}
$$

A simplified measure for the economic income, defined as the marginal return of $\mathrm{N}$ fertilization (E, CHF ha ${ }^{-1}$ ) was calculated in Eq. 7 according to Wang et al. (2019).

$$
E=Y * P_{y}-N_{a p p} * P_{N}
$$

where $\mathrm{Y}$ is the grain yield $\left(\mathrm{kg} \mathrm{ha}^{-1}\right), \mathrm{P}_{\mathrm{Y}}$ is the grain price $\left(\mathrm{CHF} \mathrm{kg}^{-1}\right), \mathrm{N}$ is the $\mathrm{N}$ fertilizer applied $\left(\mathrm{kg} \mathrm{N} \mathrm{ha}^{-1}\right), \mathrm{P}_{\mathrm{N}}$ is the $\mathrm{N}$ fertilizer price $\left(\mathrm{CHF} \mathrm{kg}{ }^{-1}\right)$. The prices of wheat grain and $\mathrm{N}$ fertilizer were 0.52 and $0.45 \mathrm{CHF} \mathrm{kg}{ }^{-1}$, respectively, in Switzerland in 2019. Currency exchange values are set at $1 \mathrm{CHF}=1.05 \mathrm{USD}=0.93 \mathrm{EUR}(\mathrm{UBS} 2020)$.

\section{Statistics}

The spectral data were extracted from the orthomosaics and analysed in a pipeline, which combined the GIS software QGIS (QGIS Development Team 2019, version 2.18) and the software RStudio Desktop (RStudio Team 2016, version 1.0.143) with R version 3.4.1 "Single Candle" (R Core Team 2017). The packages "sp", "raster", "gstat", "rgdal" and "dplyr" were used in the pipeline. The statistical analysis including the one-way ANOVA and Fisher-LSD test (package "agricolae") for the grain yield and efficiency parameters were also performed in Rstudio. In order to select the most sensitive vegetation index, 
twenty-three vegetation indices from the literature were correlated to selected plant traits namely DM, $\mathrm{N}_{\mathrm{c}}, \mathrm{N}_{\text {up }}$ and NNI using quadratic linear regression $\left(\mathrm{y}=\mathrm{x}^{2}\right) . \mathrm{R}^{2}$ and RMSE values were calculated and evaluated. The data preparation and quadratic linear regression for the sensitivity analysis between vegetation indices and selected plant traits were performed in Rstudio. The data preparation and graphics for yield and spectral data were done with the packages "dplyr", "reshape2" and "ggplot2".

\section{Results}

\section{Grain yield}

The grain yield in all fields showed no significant difference between the VR treatment and the ST treatment (Fig. 2). The fertilized treatments in fields F1, F2 and F3 were in the same range with no significant differences. The NF plots had significantly lower yield than the other treatments, except in field F4, where no significant differences were observed and yield was generally lower. Additionally, the NF treatment was not significantly different from the ST treatment in F2, where ST also tended to be lower than VR and NR. Average yields of fertilized plots were $6.9 \mathrm{t} \mathrm{ha}^{-1}$ for both $\mathrm{F} 2$ and $\mathrm{F} 3$ and $3.9 \mathrm{t} \mathrm{ha}^{-1}$ for F4. The nonfertilized plots reached 5.7, 5.3 and $4.3 \mathrm{tha}^{-1}$ for F2, F3 and F4, respectively.

The thousand-grain weight (TGW) after harvest (Table 4) showed no significant differences between ST and VR (43.74 and $43.73 \mathrm{~g}$ ) in F1 while both were above the NF weight $(41.9 \mathrm{~g})$. In 2019, the pattern was inverted; in fact, the grains in the NF plots were in all three fields about $10 \%$ heavier than the average of the fertilized plots. Protein content measured in 2019 was on average $15 \%$ for the fertilized plots with no significant differences between VR, ST and NR treatments while in the NF plots was on average $13.7 \%$. The protein content in $\mathrm{F} 4$, which yielded less grain in total, was higher compared to F2 and F3.

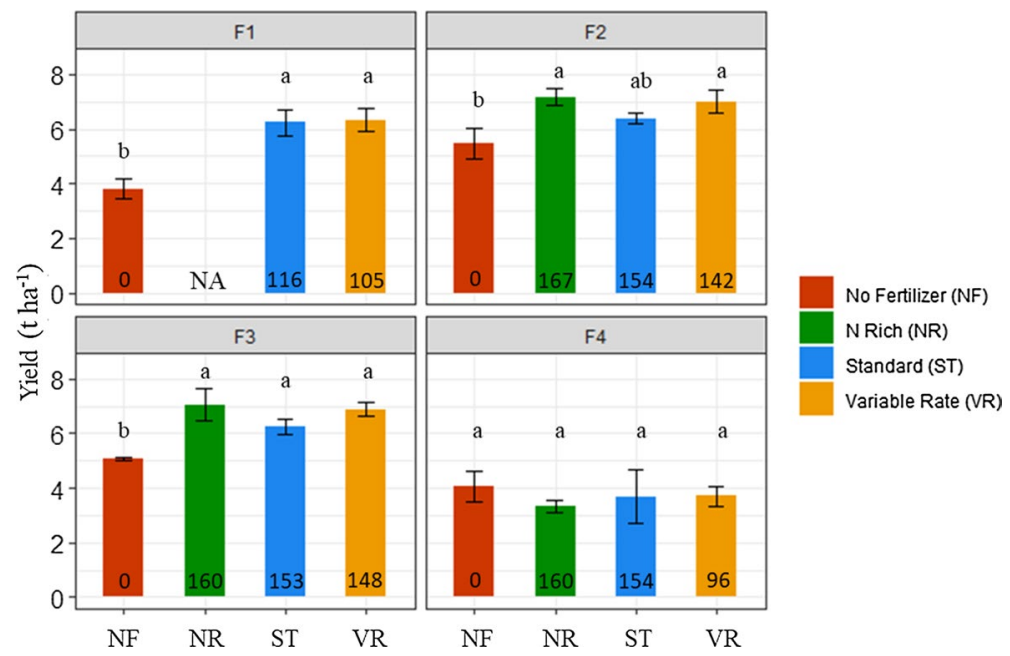

Fig. 2 Grain yield $\left(\mathrm{t} \mathrm{ha}^{-1}\right)$ of the four fields (F1, F2, F3 and F4) over two growing seasons per treatment. Error bars indicate the standard error. Letters denote significant differences between treatments according to Fisher-LSD test at $\mathrm{p}<.05$. The values inside the columns represent the average $\mathrm{N}$ rate $\left(\mathrm{kg} \mathrm{N} \mathrm{ha}^{-1}\right)$ applied in that treatment and field (Color figure online) 
Table 4 Yield and $\mathrm{N}$ - status parameters including $\mathrm{N}$ applied with the fertilizer and $\mathrm{N}$ uptake $\left(\mathrm{N}_{\text {up }}\right)$ from the crop at harvest

\begin{tabular}{|c|c|c|c|c|c|c|c|c|}
\hline & & $\begin{array}{l}\mathrm{N} \text { rate } \\
\left(\mathrm{kg} \mathrm{N} \mathrm{ha}^{-1}\right)\end{array}$ & $\begin{array}{l}\text { Grain yield } \\
\left(\mathrm{t} \mathrm{ha}^{-1}\right)\end{array}$ & $\begin{array}{l}\text { TGW } \\
(\mathrm{g})\end{array}$ & $\begin{array}{l}\mathrm{N}_{\text {up }} \text { grain } \\
\left(\mathrm{kg} \mathrm{N} \mathrm{ha}^{-1}\right)\end{array}$ & $\begin{array}{l}\mathrm{N}_{\text {up }} \text { straw } \\
\left(\mathrm{kg} \mathrm{N} \mathrm{ha}^{-1}\right)\end{array}$ & $\begin{array}{l}\mathrm{N}_{\text {up }} \text { tot } \\
\left(\mathrm{kg} \mathrm{N} \mathrm{ha}^{-1}\right)\end{array}$ & $\begin{array}{l}\text { Protein content } \\
\text { (\% of DM) }\end{array}$ \\
\hline \multicolumn{9}{|l|}{2018} \\
\hline \multirow[t]{3}{*}{ F1 } & NF & $0 \mathrm{~b}$ & $3.81 \mathrm{~b}$ & $41.9 b$ & $68 b$ & $15 b$ & $84 b$ & n.a. \\
\hline & ST & $116 a$ & $6.23 a$ & $43.74 a$ & $146 a$ & $32 a$ & $179 a$ & n.a. \\
\hline & VR & $105 a$ & $6.34 \mathrm{a}$ & $43.73 a$ & $144 \mathrm{a}$ & $35 a$ & $179 a$ & n.a. \\
\hline \multicolumn{9}{|l|}{2019} \\
\hline \multirow[t]{4}{*}{ F2 } & NF & $0 \mathrm{~d}$ & $5.48 \mathrm{~b}$ & $40.2 \mathrm{a}$ & $113 b$ & $30 \mathrm{~b}$ & $143 b$ & $13.1 \mathrm{~b}$ \\
\hline & NR & $167 \mathrm{a}$ & $7.17 \mathrm{a}$ & $36.1 \mathrm{~b}$ & $178 \mathrm{a}$ & $80 \mathrm{a}$ & $258 \mathrm{a}$ & $15.2 \mathrm{a}$ \\
\hline & ST & $154 \mathrm{~b}$ & $6.38 \mathrm{ab}$ & $34.5 b$ & $155 \mathrm{a}$ & $66 a$ & $221 \mathrm{a}$ & $14.9 \mathrm{a}$ \\
\hline & VR & $142 \mathrm{c}$ & $7.02 \mathrm{a}$ & $36.4 \mathrm{~b}$ & $163 a$ & $67 a$ & $228 \mathrm{a}$ & $14.3 \mathrm{a}$ \\
\hline \multirow[t]{4}{*}{ F3 } & $\mathrm{NF}$ & $0 \mathrm{~d}$ & $5.07 \mathrm{~b}$ & $42.9 \mathrm{a}$ & $106 \mathrm{~b}$ & $21 \mathrm{c}$ & $127 \mathrm{~b}$ & $13.1 \mathrm{a}$ \\
\hline & NR & $160 \mathrm{a}$ & $7.04 a$ & $39.2 b c$ & 136ab & $30 \mathrm{~b}$ & 166ab & $12.0 \mathrm{a}$ \\
\hline & ST & $153 b$ & $6.25 \mathrm{a}$ & $38.4 \mathrm{c}$ & $138 \mathrm{ab}$ & $47 a$ & $185 \mathrm{a}$ & $13.9 \mathrm{a}$ \\
\hline & VR & $148 \mathrm{c}$ & $6.87 \mathrm{a}$ & $39.6 \mathrm{~b}$ & $150 \mathrm{a}$ & $42 a$ & $192 a$ & $13.5 \mathrm{a}$ \\
\hline \multirow[t]{4}{*}{ F4 } & $\mathrm{NF}$ & $0 \mathrm{c}$ & $4.07 \mathrm{a}$ & $34.4 \mathrm{a}$ & $93 a$ & $45 b$ & $138 \mathrm{a}$ & $14.9 \mathrm{~b}$ \\
\hline & NR & $160 \mathrm{a}$ & $3.07 \mathrm{a}$ & $30.9 \mathrm{~b}$ & $86 a$ & $94 \mathrm{a}$ & $182 \mathrm{a}$ & $17.7 \mathrm{a}$ \\
\hline & ST & $154 \mathrm{a}$ & $3.69 \mathrm{a}$ & $30.6 \mathrm{~b}$ & $97 \mathrm{a}$ & $95 a$ & $191 \mathrm{a}$ & $16.4 \mathrm{a}$ \\
\hline & VR & $96 \mathrm{~b}$ & $3.70 \mathrm{a}$ & $30.6 \mathrm{~b}$ & $92 a$ & $86 a$ & $183 a$ & $17.1 \mathrm{a}$ \\
\hline
\end{tabular}

Letters denote the level of significance according to Fisher-LSD test at $\mathrm{p}<.05$

\section{Efficiency assessment}

The efficiency analysis showed a consistent trend whereby VR treatments performed better than ST treatments (Table 4). There were no differences in total $\mathrm{N}_{\text {up }}$ between ST and VR in grains, straw and total crop biomass; however, both were significantly higher than the NF in three of the four cases (F1-3). The soil N supply estimated from the NF plots in 2018 was $84 \mathrm{~kg} \mathrm{~N} \mathrm{ha}^{-1}$, whereas it increased in the second year ranging from 127 to $143 \mathrm{~kg} \mathrm{~N}$ $\mathrm{ha}^{-1}$. The $\mathrm{N}_{\mathrm{c}}$ measured in the grain after harvest ranged from 1.9 to $3.1 \%$ of DM and from 0.3 to $1.0 \%$ of DM in the straw. Generally, a decrease of $\mathrm{N}_{\mathrm{c}}$ from the beginning of the season (mean 4\%) until harvest (mean 1.5\%) could be observed over all four fields. The NNI values in the grain at harvest ranged from 0.6 (NF plots) to 1.2 (NR plots) with values of VR and ST plots around 0.9 on average in the four fields.

Compared to ST, the reduction of average applied $\mathrm{N}$ in the VR treatments resulted in a trend of higher AFR (Table 5). However, these differences were not significant neither for the total crop $\mathrm{N}$ nor for the grain $\mathrm{N}$ uptake $\left(\mathrm{N}_{\mathrm{up}}\right)$ only. The efficiency of grain production in relation to the $\mathrm{N}$ applied (PFP) showed a better performance of VR compared to ST in all four fields over 2 years. The marginal returns of VR also showed a trend of improved financial gain, when compared to the ST treatment. The differences ranged between 31 and $335 \mathrm{CHF}$ ha $^{-1}$ due to the reduction in applied fertilizer and, in two cases, the increase in grain yield. The NR had higher marginal returns in two out of three cases. However, these differences were statistically not significant. 
Table 5 Average apparent fertilizer recovery (AFR), yield response to $\mathrm{N}$ (PFP) and financial gain (marginal return)

\begin{tabular}{|c|c|c|c|c|c|}
\hline & & $\begin{array}{l}\mathrm{AFR}_{\mathrm{tot}} \\
(\%)\end{array}$ & $\begin{array}{l}\mathrm{AFR}_{\mathrm{g}} \\
(\%)\end{array}$ & $\begin{array}{l}\text { PFP } \\
\left(\mathrm{kg}_{\text {grain }} \mathrm{kg} \mathrm{N}^{-1}\right)\end{array}$ & $\begin{array}{l}\text { Marginal return } \\
\left(\mathrm{CHF} \mathrm{ha}^{-1}\right)\end{array}$ \\
\hline \multicolumn{6}{|l|}{2018} \\
\hline \multirow[t]{3}{*}{$\mathrm{F} 1$} & $\mathrm{NF}$ & - & - & - & $1944 b$ \\
\hline & ST & $83.1 \mathrm{a}$ & $67.2 \mathrm{a}$ & $32.9 \mathrm{~b}$ & $3161 \mathrm{a}$ \\
\hline & VR & $93.8 \mathrm{a}$ & $72.3 a$ & $60.4 a$ & $3218 a$ \\
\hline \multicolumn{6}{|l|}{2019} \\
\hline \multirow[t]{4}{*}{$\mathrm{F} 2$} & $\mathrm{NF}$ & - & - & - & $2850 \mathrm{~b}$ \\
\hline & NR & $69.1 \mathrm{a}$ & $38.9 \mathrm{a}$ & $42.9 \mathrm{~b}$ & $3652 a$ \\
\hline & ST & $50.8 \mathrm{a}$ & $27.1 \mathrm{a}$ & $41.4 b$ & $3249 a b$ \\
\hline & VR & $60.4 \mathrm{a}$ & $34.7 \mathrm{a}$ & $49.3 \mathrm{a}$ & $3584 a$ \\
\hline \multirow[t]{4}{*}{ F3 } & $\mathrm{NF}$ & - & - & - & $2635 b$ \\
\hline & NR & $24.2 \mathrm{~b}$ & $18.8 \mathrm{a}$ & $44.0 \mathrm{a}$ & $3590 \mathrm{a}$ \\
\hline & ST & $37.2 \mathrm{ab}$ & $21.1 \mathrm{a}$ & $40.9 b$ & $3183 a$ \\
\hline & VR & $42.8 \mathrm{a}$ & $29.6 a$ & $46.3 a$ & $3504 a$ \\
\hline \multirow[t]{4}{*}{$\mathrm{F} 4$} & $\mathrm{NF}$ & - & - & - & $2114 a$ \\
\hline & NR & $27.6 \mathrm{a}$ & $3.2 \mathrm{a}$ & $19.2 \mathrm{~b}$ & $1527 \mathrm{a}$ \\
\hline & ST & $34.8 \mathrm{a}$ & $2.4 \mathrm{a}$ & $23.9 b$ & $1851 \mathrm{a}$ \\
\hline & VR & $48.0 \mathrm{a}$ & $5.2 \mathrm{a}$ & $39.1 \mathrm{a}$ & $1882 \mathrm{a}$ \\
\hline
\end{tabular}

Letters denote the level of significance according to Fisher-LSD test at $\mathrm{p}<.05$

AFRtot straw + grains, AFRg AFR of grains

\section{Sensitivity analysis}

The sensitivity analysis between selected vegetation indices and plant traits (Table 6) performed on the joint dataset over the 2 years $(n=254)$ showed that by using a quadratic regression, the SVI with the highest sensitivity to both dry matter yield and $\mathrm{N}_{\text {up }}$ are those making use of the red-edge channel. The NDRE shows the best correlation and lowest error with DM $\left(\mathrm{R}^{2}=0.72\right), \mathrm{N}_{\text {up }}\left(\mathrm{R}^{2}=0.80\right)$ and NNI $\left(\mathrm{R}^{2}=0.75\right)$. Very similar results are achieved with the simple ratio NIR/RE with DM $\left(\mathrm{R}^{2}=0.70\right), \mathrm{N}_{\mathrm{up}}$ $\left(R^{2}=0.80\right)$ and NNI $\left(R^{2}=0.75\right)$. The $N_{c}$, however, showed generally low correlations and the best (0.40) was achieved with the combined index MCARI/MTVI2.

As mentioned above, NDRE was the best SVI, showing a quadratic relationship to dry matter (DM), nitrogen uptake $\left(\mathrm{N}_{\mathrm{up}}\right)$, nitrogen nutrition index (NNI) (Fig. 3). The $\mathrm{N}_{\mathrm{c}}$ curve instead, showed a quadratic decrescent curve with higher index values corresponding to lower $\mathrm{N}_{\mathrm{c}}$ values. The best index representing this relationship was the combined index MCARI/MTVI2, which, however, results in a very low correlation. Data scattering is particularly enhanced in the second biomass sampling of 2019. 
Table 6 Selected results of the quadratic linear regression model between selected vegetation indices and plant traits. Coefficient of determination $\left(\mathrm{R}^{2}\right)$ and root mean square error (RMSE) are reported for each correlation

\begin{tabular}{|c|c|c|c|c|c|c|c|c|}
\hline \multirow[t]{2}{*}{ Index } & \multicolumn{2}{|c|}{$\mathrm{DM}$} & \multicolumn{2}{|l|}{$\mathrm{N}_{\mathrm{C}}$} & \multicolumn{2}{|c|}{$\mathrm{N}_{\mathrm{up}}$} & \multicolumn{2}{|c|}{ NNI } \\
\hline & $\overline{\mathrm{R}^{2}}$ & $\overline{\text { RMSE }}$ & $\overline{\mathrm{R}^{2}}$ & $\overline{\text { RMSE }}$ & $\overline{\mathrm{R}^{2}}$ & $\overline{\text { RMSE }}$ & $\overline{\mathrm{R}^{2}}$ & $\overline{\text { RMSE }}$ \\
\hline
\end{tabular}

Simple ratios

$\begin{array}{lllllllll}\text { NIR/G } & \mathbf{0 . 7 1} & 1580 & 0.29 & 0.83 & 0.78 & 31 & 0.69 & 0.15 \\ \text { NIR/RE } & \mathbf{0 . 7 0} & 1601 & 0.19 & 0.89 & \mathbf{0 . 8 0} & 30 & \mathbf{0 . 7 5} & 0.13\end{array}$

Indices

$\begin{array}{lllllllll}\text { NDVI } & 0.55 & 1986 & 0.33 & 0.81 & 0.58 & 43 & 0.57 & 0.18 \\ \text { GNDVI } & 0.69 & 1639 & 0.29 & 0.83 & 0.75 & 33 & 0.68 & 0.15 \\ \text { MTVI2 } & 0.65 & 1738 & 0.31 & 0.82 & 0.70 & 36 & 0.62 & 0.17 \\ \text { NDRE } & \mathbf{0 . 7 2} & 1573 & 0.19 & 0.89 & \mathbf{0 . 8 0} & 29 & \mathbf{0 . 7 5} & 0.13\end{array}$

Combined indices

\begin{tabular}{lllllllll} 
MCARI/MTVI2 & 0.30 & 2464 & $\mathbf{0 . 4 0}$ & 0.77 & 0.30 & 56 & 0.30 & 0.22 \\
\hline
\end{tabular}

Bold numbers indicate the highest coefficients of correlation that were observed
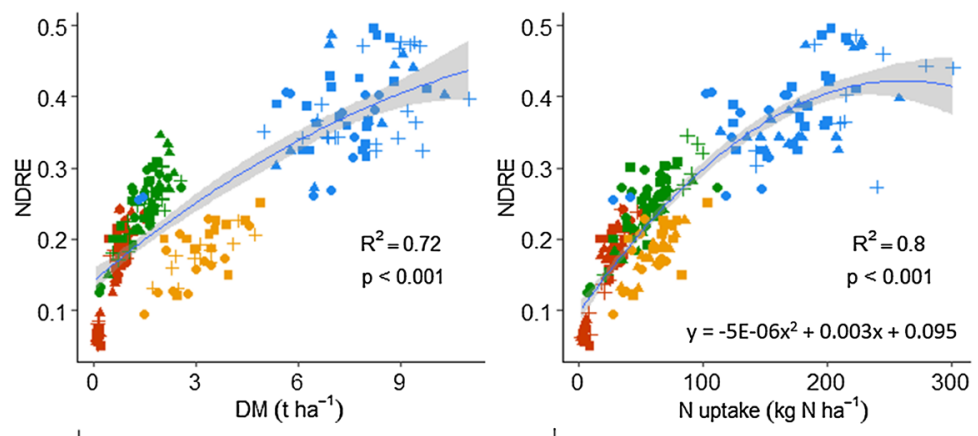

- No Fertilizer (NF)

+ Nitrogen Rich (NR)

- Standard (ST)

- Variable Rate (VR)
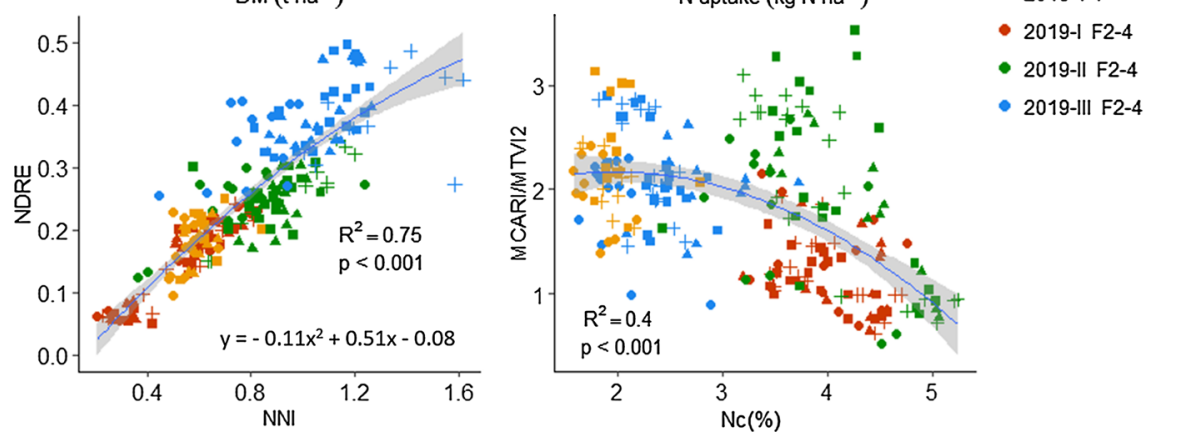

Fig. 3 Relationship of NDRE with DM, $\mathrm{N}_{\mathrm{up}}$, NNI and MCARI/MTVI2 with $\mathrm{N}_{\mathrm{c}}$. The data were derived from four biomass and spectral sampling campaigns (different colours) at different growth stages over the 2 years $(\mathrm{n}=254)$. F1 was sampled in 2018 at BBCH 32. F2-F4 in 2019 at BBCH 25 (I), BBCH 31 (II) and $\mathrm{BBCH} 39$ (III) (Color figure online) 


\section{Seasonal dynamic of NDRE compared to NDVI}

The seasonal development of NDRE and NDVI of the studied fields showed different characteristics over time. The NDRE data extracted from each plot and averaged per treatment from field F1 to F2 showed a steady increase from the time of the first split fertilization (beginning of stem elongation), to its peak at the beginning of the spike emergence (Fig. 4, left). After flowering and during senescence the intensity of the signal decreased. The $\mathrm{N}$ input treatments were clearly separable during the assumed fertilization period from stem elongation to spike appearance. In F1, the fertilized treatments VR and ST were significantly different from the NF treatment starting from DAS 200. In F2, NR was significantly higher than NF from DAS 195 on. AT DAS 203, there was a significant difference between treatments: NR $>$ VR, ST $>$ NF. The fertilized treatments were then in the same range and separable from NF until late senescence.

In contrast to NDRE, NDVI (Fig. 4, right) saturated at the beginning of the season shortly after stem elongation before decreasing rapidly during the senescence phase. The fertilizer treatments generally did not show distinct differences between each other. In F1, the differences between NF treatment and the fertilized treatments VR and ST were significant later in the season from DAS 214 on. In F2, there were no significant differences between treatments. In comparison, with NDRE the relative difference
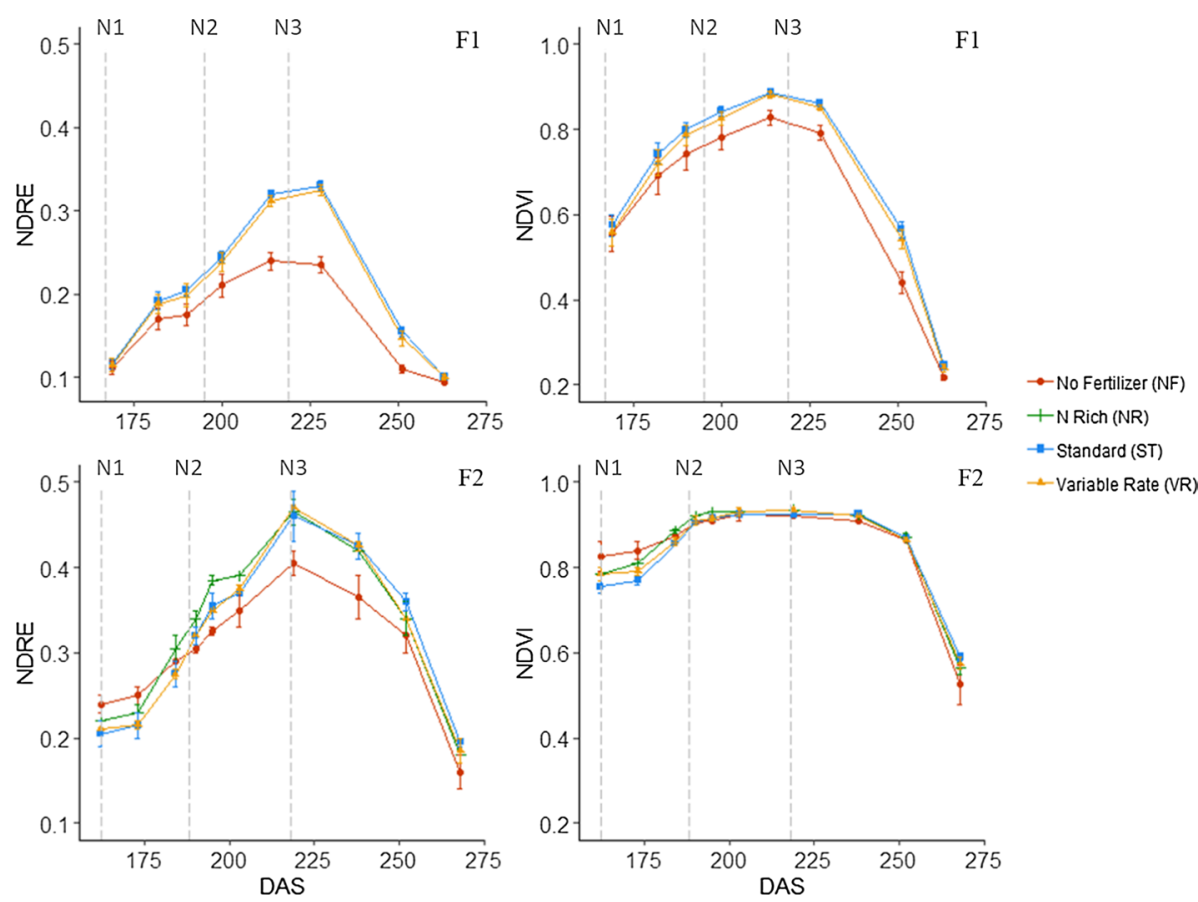

Fig. 4 Comparison of seasonal patterns of NDRE and NDVI for 2018 (F1) and 2019 (F2). Each measurement point represents average values per treatment with standard error. Time is represented on the $\mathrm{x}$-axis as days after sowing (DAS). The grey lines N1, N2 and N3 denote the first, second and third split fertilizer applications, respectively. For $\mathrm{F} 1, \mathrm{~N} 1=\mathrm{BBCH} 23, \mathrm{~N} 2=\mathrm{BBCH} 32$ and N3=BBCH45. For F2, N1=BBCH $25, \mathrm{~N} 2=\mathrm{BBCH} 31$ and $\mathrm{N} 3=\mathrm{BBCH} 39$ (Color figure online) 
between fertilized and non-fertilized plots was clearly visible. The fields F3 and F4 showed a similar behaviour (Supplementary Fig. 1).

\section{Discussion}

Yield analysis confirmed the hypothesis that site-specific fertilization is able to reduce total $\mathrm{N}$ application without a loss of yield in the small-to-medium-sized agricultural system investigated in Switzerland being in line with the findings of Stamatiadis et al. (2018) and Wang et al. (2019). In three out of four cases (F1, F2 and F3), grain yield (6.5-7.5 $\mathrm{tha}^{-1}$ ) and protein content (14-15\%) were in the range of the Swiss average for top quality wheat varieties (Levy and Brabant 2016; Sinaj and Richner 2017; Hofer 2019). In F4, the lower yield and lack of differences between all treatments could be explained by the combination of the late sowing date (1 month later than F2 and F3) and excessive damage provoked by the mechanical weeding with the tined harrow combined with the insufficient establishment of the wheat plants in early spring. Consequently, the field showed very heterogeneous patches of crop development (data not shown).

\section{Remote sensing as a base for variable rate application}

A literature survey reflected that a broad range of spectral indices is used for the prediction of in-field N status of crops (Heege et al. 2008; Heege 2013; Li et al. 2014; Prey and Schmidhalter 2019; Zhao et al. 2018). To confirm the applicability of the selected SVI for the given camera setting, a sensitivity analysis was conducted investigating twenty-three SVI from the literature survey applicable to the camera band combination. Most of them were shown to be sensitive to either canopy structure, biomass or N status (Basso et al. 2016; Bendig et al. 2015; Chen 2015; Cilia et al. 2014; Schmidhalter et al. 2003). The study clearly showed that indices combining RE and NIR like NDRE and NIR/RE ratio indeed had the best correlation with the N-status traits $\mathrm{N}_{\text {up }}$ and NNI in this study. The correlation value $\left(\mathrm{R}^{2}=0.80\right.$ and $\mathrm{R}^{2}=0.75$ for the $\mathrm{N}_{\text {up }}$ and NNI, respectively) confirmed the assumption that NDRE can be used to monitor the $\mathrm{N}$ status of the wheat field. Bean et al. (2018) reported similar observations for corn $\mathrm{N}$ side dress also pointing to a superiority of RE-NIR based spectral indices over red-NIR based ones like NDVI. The seasonal monitoring patterns of NDVI and NDRE reflected climate and field management affecting the plants' growth. The NDVI curves saturate at the time of the second split fertilizer application, earlier than the NDRE. In Fig. 4, NDVI curves for F1 and F2 showed a high saturation already at 190 days after sowing corresponding to BBCH 29-30, between canopy closure and beginning of stem elongation (Baret and Guyot 1991). At this stage, NDRE is still increasing with values around 0.3-0.4. Because of the early saturation, NDVI is less useful for the derivation of $\mathrm{N}$ fertilizer prescription maps for the second and third fertilizer application. However, NDVI seems to be a viable N status indicator for a first $\mathrm{N}$ application when the canopy is not yet closed. The NDRE development was linear until the stage of spike emergence, which takes place after the third and last fertilizer application in winter wheat and therefore NDRE and NIR/RE are a better base for the creation of fertilizer prescription maps than NDVI or the other investigated SVIs.

Although NDRE allows quantifying $\mathrm{N}_{\mathrm{up}}$, the relatively large variability suggests a qualitative assessment, linking NDRE to the general fertilization strategy. In this study, the N fertilizer prescription for VR was based on the NDRE index map combined with the Swiss standard fertilization recommendation indicating the average $\mathrm{N}$ demand subsequently 
adjusted for higher or lower NDRE values. The choice to use the average value as reference was supported by the presence of non-fertilized and surplus-fertilized plots in the trial acting as minimum and maximum reference values, respectively. However, other approaches to obtain fertilizer prescription maps were suggested. Holland and Schepers (2013) and Stamatiadis et al. (2018) used the 95th percentile of the histogram produced with spectral index values of the whole field. In other studies, the yield response to $\mathrm{N}$-application in combination with spectral indices were used to predict the $\mathrm{N}$-application rate (Bean et al. 2018; Franzen et al. 2016; Holland and Schepers 2010; Raun et al. 2005). This study indicates that the use of NDVI is less sensitive for in-season fertilization support, despite being a commonly used solution in other studies (Tremblay et al. 2009; Walsh et al. 2013; Wood et al. 2003). Nevertheless, for early season fertilizer application NDVI seems to provide a reliable approximation of biomass. In-depth studies are needed to clarify the sensitivity change of spectral indices in relation to crop development features like canopy coverage to suggest the optimal sensing strategy to support in-season fertilizer application.

For the determination of the field variability by imaging, the use of a UAV system was superior to satellite data in this study (data not shown), because the plot size of the experiments was relatively small and delineation of the plots with satellite pixels such as Sentinel-2 was not robust, creating interference in the plot measurement precision. However, if considering the whole field level, the identification of $\mathrm{N}$-status and extraction of fertilization prescription maps would be feasible from such satellite data. In fact, the information contained in the UAV images needed to be down-sampled to match the resolution of the application map for the tractor terminal of a minimum $7 \times 7 \mathrm{~m}$ (derived by testing). In general, satellite images with a resolution of $10 \times 10 \mathrm{~m}$ such as for Sentinel-2 are therefore a viable basis for creating prescription maps. Nonetheless, the drone-based approach allowed to study the vegetation development in more detail and to obtain information even on cloudy days, which can be an advantage in climates and regions in which the first and the second $\mathrm{N}$ fertilization split is usually performed during cloudy spring periods like in Switzerland. Therefore, the outlined approaches might lead to a more favourable use of small-scale equipment for the management of small-to-medium-sized agricultural systems in future. Based on such approaches, it might become possible to return to smaller sized tractors or even to use smaller machinery such as robots or small autonomous tractors equipped with pneumatic spreader systems, which can distribute fertilizer at a finer scale and thus may use prescription maps with higher resolution.

The characterization of the soil variability and crop growth variation is an important step to understand, whether variable rate application methodology is viable for a certain field or not (Griepentrog et al. 2007; Heege 2013). The four field case studies presented in this study showed various degrees of variability mainly due to underlying soil properties but also due to weather differences. Field F3 was relatively homogeneous and therefore the average saving of $\mathrm{N}$ fertilizer was only about $5 \%$. Nonetheless, the redistribution of fertilizer had a positive effect on yield and NUE. The influence of climate was crucial for F1, as 2018 was a very dry season $\left(475 \mathrm{~mm}\right.$ cumulative rainfall and mean $\mathrm{T} 10.5^{\circ} \mathrm{C}$ in January-July 2018). However, for field F1 the combination of the dry season and a commonly water-stagnating soil was beneficial. In the central zone of the field, which had a higher level of organic matter and water holding capacity, likely supporting a higher $\mathrm{N}$ mineralisation, it was possible to reduce the fertilizer amount down to $30-35 \%$ in two VR plots, without loss in yield. The season 2019 instead was a wet season with generally beneficial weather (657 $\mathrm{mm}$ and $\mathrm{T} 9.5{ }^{\circ} \mathrm{C}$ January-July 2019) which was reflected in the higher soil $\mathrm{N}$ supply in the NF compared to the previous year. The favourable weather conditions combined with the high $\mathrm{N}$-mineralisation rate of the soil during the vegetation period likely led 
to a good grain filling and higher TGW in the NF-plots. Ultimately, a deeper understanding of $\mathrm{N}$ mineralization potential, related to spatially and temporally varying environmental conditions, is necessary to define the most efficient fertilization strategy. The use of models or sensor-based information could help to better understand the dynamics of $\mathrm{N}$ throughout the season (Yin et al. 2020).

\section{Environmental and economic efficiency}

A general trend towards improved efficiency was observed in three of the four cases studies. The total wheat crop $\mathrm{N}_{\text {up }}$ was similar between fertilized treatments, indicating that the impact of the reduction in applied $\mathrm{N}$ on $\mathrm{N}_{\mathrm{up}}$ from the VR treatments was compensated by the improved spatial distribution. The reduction of applied $\mathrm{N}$ over all plots and the 4 years ranged from 5 to $40 \%$ of the standard N fertilization. PFP was the only efficiency indicator that resulted in significant differences between treatments. In this sense, the yield production in relation to the $\mathrm{N}$ applied was improved with VR application compared to ST. Whereas in 2018 a very high AFR of around 90\% was obtained, in 2019 lower values around 24-69\% were observed. The reason was that the soil in 2018 only supplied $84 \mathrm{~kg}$ $\mathrm{N} \mathrm{ha}^{-1}$ (NF plots) due to the very dry climate. In 2019, the $\mathrm{N}$ replenishment from the soil was much higher (127-143 $\mathrm{kg} \mathrm{N} \mathrm{ha}^{-1}$ ). This might mean that the subsequent soil supply largely covered the $\mathrm{N}$ requirement of the plants and thus led to a very low $\mathrm{N}$ fertilizer utilization. Although it is not possible to know which part of the applied $\mathrm{N}$ or soil $\mathrm{N}$ was taken up by the plants, this is a clear indication of lower fertilizer NUE and of an increased risk of $\mathrm{N}$ loss. In 2019, F2 had higher $\mathrm{N}_{\text {min }}$ (Table 2) and yield, therefore it is conceivable that the lower first application resulted in higher efficiency compared to F3 and F4. The use of image or sensor data is not sufficient to identify seasonal total $\mathrm{N}$ needs of the crop with high precision but arguably, the set of calculation applied to the data might have been a limitation.

In this study, it was not possible to directly estimate the emission of $\mathrm{N}$ via leaching and denitrification. However, the active $\mathrm{N}$ pool in the system can be estimated by summing the $\mathrm{N}_{\text {up }}$ from the NF treatments, as measure for soil $\mathrm{N}$ supply during the winter wheat season, to the $\mathrm{N}$ applied in the fertilized treatments. Subtracting $\mathrm{N}_{\text {up }}$ in the fertilized treatments from this active $\mathrm{N}$ pool reflects the approximate quantity of $\mathrm{N}$ left in the system after harvest prone to be lost or immobilized. In both years, the VR treatments showed a lower $\mathrm{N}$ loss risk. Whereas in 2018 the values were generally low and risk for $\mathrm{N}$ loss was $50 \%$ lower for VR than for ST (10 kg N ha ${ }^{-1}$ for VR and $21 \mathrm{~kg} \mathrm{~N} \mathrm{ha}^{-1}$ for ST in F1), in 2019 the values were higher and VR was on average $30 \%$ lower than ST and NR (63 kg N ha ${ }^{-1}$ for VR and $90 \mathrm{~kg} \mathrm{~N} \mathrm{ha}^{-1}$ for ST and NR in F2-F3) (Supplementary Table 2). Both VR application of fertilizers and considering soil $\mathrm{N}$ analysis for optimal $\mathrm{N}$ supply are viable methods to reduce the risk for $\mathrm{N}$ losses. The combination of both very likely creates a synergy in the reduction for field and farm management of $\mathrm{N}$.

Marginal returns offer a simplified economic balance between the cost of fertilizer and the gain from the sale of the grain to the mill. The improved gain of VR when compared to the ST ranged from $1.6 \%$ corresponding to $31 \mathrm{CHF} \mathrm{ha}^{-1}$ to $9.3 \%$ corresponding to 335 $\mathrm{CHF} \mathrm{ha}{ }^{-1}$. This evaluation does not take parameters such as the investment costs to obtain prescription maps or cost for the technology and machinery into account. Furthermore, in small-scale farming, a higher marginal return per ha might not be fully sufficient to sustain the required investments. Considering a scenario in which sufficient knowledge is available to the point that higher returns for a certain threshold of variability in the field can be 
guaranteed, cantonal or governmental authorities could consider measures to support the transition to VR technology for farmers. Another strategy could be to encourage farm contractors providing VR fertilization services.

\section{Conclusions}

The methods applied were suitable to characterize in-field variability and were able to increase the nitrogen use efficiency. Also under Swiss conditions, NDRE showed a better differentiation of the N-status of the plants, than NDVI. The potential for further improvements lies primarily in the extent of the variability of $\mathrm{N}$ availability in the soil and resulting crop growth within the field, but also in a better understanding of mineralization processes. Easily collectable visual data that cover fields with a high spatial resolution can help to close this gap. Ultimately, better quantification of the variability in terms of $\mathrm{N}$ status and plant growth is necessary to set a threshold for deciding if variable rate application is worth being implemented in a designated field. However, VRA of $\mathrm{N}$ has the potential to reduce fertilizer inputs while keeping yields at current levels, in particular when combined with soil $\mathrm{N}_{\min }$ information. Thus, it represents a viable tool among others to improve NUE in cropping systems and reduce $\mathrm{N}$ losses to the environment. The methodology may support increasing sustainability of small to medium scale agriculture by increasing financial return and decreasing the environmental footprint of arable cropping systems.

Acknowledgements The authors would like to thank the Swiss centre of excellence for agricultural research Agroscope, affiliated with the Federal Office of Agriculture (FOAG), for funding the project. Furthermore, we thank Matthias Hatt, Marianne Cockburn, Mirjam Mattei and Brigitta Herzog from Agroscope and ETH Zürich for the technical support during data collection and analysis, as well as Marco Landis and Christian Schenk at the Swiss Future Farm for the support in the field trial management. Finally, thanks to the colleagues of the ETH PhenoFly team Helge Aasen, Lukas Roth and Quirina Merz for helping with the set-up of the UAV system and measurements. The authors would also like to thank the Swiss National Science Foundation for funding the project 407340_172433, Innofarm, that stimulated a number of ideas that were beneficial for this manuscript.

Funding Funding was provided by Swiss centre ofexcellence for agricultural research-Agroscope.

Data availability The plant and spectral data that support the findings of this study, as well as the supplementary material, are available in the online repository with the identifier, https://doi.org/10.3929/ ethz-b-000380508. At https://www.research-collection.ethz.ch/handle/20.500.11850/380508 last accessed [09/06/2020].

\section{Compliance with ethical standards}

Conflict of interest The authors declare that they have no conflict of interest.

Open Access This article is licensed under a Creative Commons Attribution 4.0 International License, which permits use, sharing, adaptation, distribution and reproduction in any medium or format, as long as you give appropriate credit to the original author(s) and the source, provide a link to the Creative Commons licence, and indicate if changes were made. The images or other third party material in this article are included in the article's Creative Commons licence, unless indicated otherwise in a credit line to the material. If material is not included in the article's Creative Commons licence and your intended use is not permitted by statutory regulation or exceeds the permitted use, you will need to obtain permission directly from the copyright holder. To view a copy of this licence, visit http://creativecommons.org/licenses/by/4.0/. 


\section{References}

Aasen, H., Honkavaara, E., Lucieer, A., \& Zarco-Tejada, P. J. (2018). Quantitative remote sensing at ultrahigh resolution with UAV spectroscopy: A review of sensor technology, measurement procedures, and data correction workflows. Remote Sensing, 10, 1-42.

Agroscope (1995), Reference method for extraction of $\mathrm{NO}_{3}-\mathrm{N}$ and $\mathrm{NH}_{4}-\mathrm{N}$ to estimate soil mineral nitrogen $\left(\mathrm{N}_{\text {min }}\right)$, Swiss federal centre for agricultural research Agroscope.

Argento, F., Anken, T., Liebisch, F., \& Walter, A. (2019). Crop imaging and soil adjusted variable rate nitrogen application in winter wheat. In Precision Agriculture'19. Proceedings of the 12th European conference on precision agriculture. (pp. 800-816). Wageningen, The Netherlands: Wageningen Academic Publishers.

Baret, F., \& Guyot, G. (1991). Potentials and limits of vegetation indices for LAI and APAR assessment. Remote Sensing of Environment, 35(2-3), 161-173.

Barnes, E. M., Clarke, T. R., Richards, S. E., Colaizzi, P. D., Haberland, J., Kostrzewski, M., et al. (2000). Coincident detection of crop water stress, nitrogen status and canopy density using ground based multispectral data. In Proceedings of the fifth international conference on Precision Agriculture, (Vol. 1619) Bloomington, MN, USA.

Basso, B., Fiorentino, C., Cammarano, D., \& Schulthess, U. (2016). Variable rate nitrogen fertilizer response in wheat using remote sensing. Precision Agriculture, 17, 168-182.

Bean, G. M., Kitchen, N. R., Camberato, J. J., Ferguson, R. B., Fernandez, F. G., Franzen, D. W., et al. (2018). Active-optical reflectance sensing corn algorithms evaluated over the United States Midwest Corn Belt. Agronomy Journal, 110(6), 2552-2565.

Bendig, J., Yu, K., Aasen, H., Bolten, A., Bennertz, S., Broscheit, J., Gnyp, M. L., et al. (2015). Combining UAV-based plant height from crop surface models, visible and near-infrared vegetation indices for biomass monitoring in barley. International Journal of Applied Earth Observation and Geoinformation, 39, 79-87.

Berger, K., Verrelst, J., Féret, J. B., Wang, Z., Wocher, M., Strathmann, M., et al. (2020). Crop nitrogen monitoring: Recent progress and principal developments in the context of imaging spectroscopy missions. Remote Sensing of Environment, 242, 111758.

Buschmann, C., \& Nagel, E. (1993). In vivo spectroscopy and internal optics of leaves as basis for remote sensing of vegetation. International Journal of Remote Sensing, 14(4), 711-722.

Cammarano, D., Fitzgerald, G., Basso, B., O’Leary, G., Chen, D., Grace, P., et al. (2011). Use of the Canopy Chlorophyll Content Index (CCCI) for remote estimation of wheat nitrogen content in rainfed environments. Agronomy Journal, 103, 1597-1603.

Chen, P. (2015). A comparison of two approaches for estimating the wheat nitrogen nutrition index using remote sensing. Remote Sensing, 7(4), 4527-4548.

Chen, G. F., Cao, H. Z., Chen, D. D., Zhang, L. B., Zhao, W. L., Zhang, Y., et al. (2019). Developing sustainable summer maize production for smallholder farmers in the North China Plain: An agronomic diagnosis method. Journal of Integrative Agriculture, 18(8), 1667-1679.

Cilia, C., Panigada, C., Rossini, M., Meroni, M., Busetto, L., Amaducci, S., et al. (2014). Nitrogen status assessment for variable rate fertilization in maize through hyperspectral imagery. Remote Sensing, 6 , 6549-6565.

Cohan, J., Soenen, B., Vericel, G., \& Laurent, F. (2018). Improving nitrogen use efficiency in wheat: recent progress and prospects in France. In Proceedings of Phloème, first biennials of cereal innovation, Paris, 24th-25th January 2018.

Diacono, M., Rubino, P., \& Montemurro, F. (2013). Precision nitrogen management of wheat. A review. Agronomy for Sustainable Development, 33, 219-241.

Ebertseder, T., Gutser, R., Hege, U., Brandhuber, R., \& Schmidhalter, U. (2003). Strategies for site-specific nitrogen fertilization with respect to long-term environmental demands. In Precision Agriculture. In Proceedings of the 4th European conference on Precision Agriculture. (pp. 193-198). Wageningen, The Netherlands: Wageningen Academic Publishers.

Eitel, J. U. H., Long, D. S., Gessler, P. E., \& Smith, A. M. S. (2007). Using in-situ measurements to evaluate the new RapidEye ${ }^{\mathrm{TM}}$ satellite series for prediction of wheat nitrogen status. International Journal of Remote Sensing, 28(18), 4183-4190.

EUROSTAT (2016). Distribution of EU farms and utilised agricultural area according to farm size. Retrieved June 9, 2020, from https://ec.europa.eu/eurostat/statistics-explained.

FAO (2014). World Reference Base for Soil Resources WRB, International Soil Classification System for Naming Soils and Creating Legends for Soil Maps.

Féret, J. B., Berger, K., de Boissieu, F., \& Malenovský, Z. (2020). PROSPECT-PRO for estimating content of nitrogen-containing leaf proteins and other carbon-based constituents. arXiv:2003.11961. 
Franzen, D., Kitchen, N., Holland, K., Schepers, J., \& Raun, W. (2016). Algorithms for in-season nutrient management in cereals. Agronomy Journal, 108(5), 1775-1781.

FSO. (2019). Agriculture and food: Pocket statistics 2019. Swiss Federal Statistical Office. Retrieved June 9, 2020 from, https://www.bfs.admin.ch/bfs/en/home/statistics/agriculture-forestry/farming.assetdetai 1.8706379.html.

Gabriel, J. L., Zarco-Tejada, P. J., López-Herrera, P. J., Pérez-Martín, E., Alonso-Ayuso, M., \& Quemada, M. (2017). Airborne and ground level sensors for monitoring nitrogen status in a maize crop. Biosystems Engineering, 160, 124-133.

Griepentrog, H. W., Thiessen, E., Kristensen, H., \& Knudsen, L. (2007). A patch-size index to assess machinery to match soil and crop spatial variability. In Precision Agriculture. Proceedings of 6th European conference on Precision Agriculture. (pp. 407-413). Wageningen, The Netherlands: Wageningen Academic Publishers.

Haboudane, D., Miller, J. R., Pattey, E., Zarco-Tejada, P. J., \& Strachan, I. B. (2004). Hyperspectral vegetation indices and novel algorithms for predicting green LAI of crop canopies: Modeling and validation in the context of precision agriculture. Remote Sensing of Environment, 90(3), 337-352.

Hansen, B., Thorling, L., Schullehner, J., Termansen, M., \& Dalgaard, T. (2017). Groundwater nitrate response to sustainable nitrogen management. Scientific Reports, 7(1), 1-12.

Heege, H. J. (2013). Precision in crop farming: Site-specific concepts and sensing methods: applications and results. Dordrecht: Springer.

Heege, H. J., Reusch, S., \& Thiessen, E. (2008). Prospects and results for optical systems for site-specific on-the-go control of nitrogen-top-dressing in Germany. Precision Agriculture, 9(3), 115-131.

Hofer, M. (2019), Swiss Granum annual report on bread wheat-Swiss industry organization for cereals, oilseeds and protein crops. Retrieved June 9, 2020, from https://www.bfs.admhttps://www.swissgranu m.ch/.

Holland, K. H., \& Schepers, J. S. (2010). Derivation of a variable rate nitrogen application model for inseason fertilization of corn. Agronomy Journal, 102(5), 1415-1424.

Holland, K. H., \& Schepers, J. S. (2013). Use of a virtual-reference concept to interpret active crop canopy sensor data. Precision Agriculture, 14(1), 71-85.

Howard, P. J. A. (1965). The carbon-organic matter factor in various soil types. Oikos, 15, 229-236.

Hunt, E. R., Jr., \& Daughtry, C. S. (2018). What good are unmanned aircraft systems for agricultural remote sensing and precision agriculture? International Journal of Remote Sensing, 39(15-16), 5345-5376.

Hunt, A. G., Sharp, J. M., Johnstone, P. R., \& Searle, B. P. (2019). Dividing the risk-theoretical exploration of increasing N management temporal granularity in maize. In Precision Agriculture'19. Proceedings of the 12th European conference on Precision Agriculture. (pp. 531-537). Wageningen, The Netherlands: Wageningen Academic Publishers.

Jan, P., Calabrese, C., \& Lips, M. (2017). Determinants of nitrogen surplus at farm level in Swiss agriculture. Nutrient Cycling in Agroecosystems, 109(2), 133-148.

Justes, E., Mary, B., Meynard, J. M., Machet, J. M., \& Thelier-Huché, L. (1994). Determination of a critical nitrogen dilution curve for winter wheat crops. Annals of Botany, 74(4), 397-407.

Khan, Z., Chopin, J., Cai, J., Eichi, V. R., Haefele, S., \& Miklavcic, S. (2018). Quantitative estimation of wheat phenotyping traits using ground and aerial imagery. Remote Sensing, 10(6), 950.

Kindred, D. R., Milne, A. E., Webster, R., Marchant, B. P., \& Sylvester-Bradley, R. (2015). Exploring the spatial variation in the fertilizer-nitrogen requirement of wheat within fields. The Journal of Agricultural Science, 153(1), 25-41.

Lassaletta, L., Billen, G., Grizzetti, B., Anglade, J., \& Garnier, J. (2014). 50-year trends in nitrogen use efficiency of world cropping systems: The relationship between yield and nitrogen input to cropland. Environmental Research Letters, 9(10), 105011.

Levy, L., \& Brabant, C. (2016). "Die Kunst, den Stickstoffdünger für einen optimalen Ertrag und Proteingehalt von Weizen aufzuteilen" (the art of splitting nitrogen applications to optimise wheat yield and protein content). Agrarforschung Schweiz, 7, 80-87.

Li, F., Miao, Y., Feng, G., Yuan, F., Yue, S., Gao, X., et al. (2014). Improving estimation of summer maize nitrogen status with red edge-based spectral vegetation indices. Field Crops Research, 157, 111-123.

Li, J., Shi, Y., Veeranampalayam-Sivakumar, A. N., \& Schachtman, D. P. (2018). Elucidating sorghum biomass, nitrogen and chlorophyll contents with spectral and morphological traits derived from unmanned aircraft system. Frontiers in Plant Science, 9, 1406.

Liebisch, F., Küng, G., Damm, A., \& Walter, A. (2014). Characterization of crop vitality and resource use efficiency by means of combining imaging spectroscopy-based plant traits. In 6th workshop on hyperspectral image and signal processing: Evolution in Remote Sensing (WHISPERS) (pp. 1-4). IEEE.

Liebisch, F., Pfeifer, J., Müller-Ruh, C., \& Walter, A. (2017). Proximal and remote quantification of nitrogen fertilizer demand-a case study in sugar beet. In Proceedings of the XVIII international plant nutrition 
colloquium with boron and manganese satellite meetings (pp. 266-267). University of Copenhagen, Department of Plant and Environmental Sciences.

Matese, A., Toscano, P., Di Gennaro, S., Genesio, L., Vaccari, F., Primicerio, J., et al. (2015). Intercomparison of UAV, aircraft and satellite remote sensing platforms for precision viticulture. Remote Sensing, 7(3), 2971-2990.

Mattei, M., Argento, F., \& Cockburn, M. (2020). Evaluation of Soil Data Interpolation Methods. 40. GILJahrestagung, Digitalisierung für Mensch, Umwelt und Tier (Annual conference, Digitalisation for mankind, environment and animals).

Meier, U., Bleiholder, H., Buhr, L., Feller, C., Hack, H., Heß, M., et al. (2009). The BBCH system to coding the phenological growth stages of plants-history and publications. Journal für Kulturpflanzen, 61(2), 41-52.

Muñoz-Huerta, R. F., Guevara-Gonzalez, R. G., Contreras-Medina, L. M., Torres-Pacheco, I., PradoOlivarez, J., \& Ocampo-Velazquez, R. V. (2013). A review of methods for sensing the nitrogen status in plants: advantages, disadvantages and recent advances. Sensors (Basel, Switzerland), 13(8), $10823-10843$.

NABODAT (2019). Agroscope: Swiss Soil Monitoring Network (NABO). Retrieved June 9, 2020, from, https://www.nabodat.ch/index.php/de/.

Nawar, S., Corstanje, R., Halcro, G., Mulla, D., \& Mouazen, A. M. (2017). Delineation of soil management zones for variable-rate fertilization: A review. In: Advances in agronomy, Vol. 143, pp. 175-245, Academic Press, Cambridge.

ÖLN (2018). "Ökologischer Leistungsnachweis" (ecological proof of performance for direct payment in Switzerland). Retrieved June 9, 2020, from https://www.blw.admin.ch/blw/de/home/instrumente/ direktzahlungen/oekologischer-leistungsnachweis.html.

Prey, L., \& Schmidhalter, U. (2019). Sensitivity of vegetation indices for estimating vegetative N status in winter wheat. Sensors (Basel, Switzerland), 19(17), 3712.

Prost, L., \& Jeuffroy, M. H. (2007). Replacing the nitrogen nutrition index by the chlorophyll meter to assess wheat N status. Agronomy for Sustainable Development, 27(4), 321-330.

QGIS Development Team (2019). QGIS Geographic Information System. Open Source Geospatial Foundation Project. Retrieved June 9, 2020, from http://qgis.osgeo.org .

R Core Team. (2017). R: A language and environment for statistical computing. R Foundation for Statistical Computing: Vienna, Austria.

Raun, W. R., Solie, J. B., Johnson, G. V., Stone, M. L., Mullen, R. W., Freeman, K. W., et al. (2002). Improving nitrogen use efficiency in cereal grain production with optical sensing and variable rate application. Agronomy Journal, 94(4), 815-820.

Raun, W. R., Solie, J. B., Stone, M. L., Martin, K. L., Freeman, K. W., Mullen, R. W., et al. (2005). Optical sensor-based algorithm for crop nitrogen fertilization. Communications in Soil Science and Plant Analysis, 36(19-20), 2759-2781.

Ravier, C., Jeuffroy, M. H., Gate, P., Cohan, J. P., \& Meynard, J. M. (2018). Combining user involvement with innovative design to develop a radical new method for managing $\mathrm{N}$ fertilization. Nutrient Cycling in Agroecosystems, 110(1), 117-134.

Roth, L., Hund, A., \& Aasen, H. (2018). PhenoFly planning tool: Flight planning for high-resolution optical remote sensing with unmanned areal systems. Plant Methods, 14(1), 116.

Rouse, J. W., Haas, R. H., Schell, J. A., \& Deering, D. W. (1974). Monitoring vegetation systems in the Great Plains with ERTS, vol. 351. NASA Special Publication, Washington, pp. 309.

RStudio Team (2016). RStudio: Integrated Development for R. Boston, MA: RStudio, Inc. Retrieved June 9, 2020, from, http://www.rstudio.com/.

Samborski, S. M., Tremblay, N., \& Fallon, E. (2009). Strategies to make use of plant sensors-based diagnostic information for nitrogen recommendations. Agronomy Journal, 101(4), 800-816.

Schmidhalter, U., Jungert, S., Bredemeier, C., Gutser, R., Manhart, R., Mistele, B., et al. (2003). Fieldscale validation of a tractor based multispectral crop scanner to determine biomass and nitrogen uptake of winter wheat. In Precision agriculture. Proceedings from the 4th European Conference on Precision Agriculture . (pp. 615-619). Wageningen, The Netherlands: Wageningen Academic Publishers.

Sinaj, S., \& Richner, W. (2017). Principles of fertilization of agricultural crops in Switzerland (PRIF 2017). Agrarforschung Schweiz, https://doi.org/10.3920/978-90-8686-888-9_63.

Spiess, E. (2011). Nitrogen, phosphorus and potassium balances and cycles of Swiss agriculture from 1975 to 2008. Nutrient Cycling in Agroecosystems, 91(3), 351-365.

Stamatiadis, S., Schepers, J. S., Evangelou, E., Tsadilas, C., Glampedakis, A., Glampedakis, M., et al. (2018). Variable-rate nitrogen fertilization of winter wheat under high spatial resolution. Precision Agriculture, 19(3), 570-587. 
Tremblay, N., Wang, Z., Ma, B. L., Belec, C., \& Vigneault, P. (2009). A comparison of crop data measured by two commercial sensors for variable-rate nitrogen application. Precision Agriculture, 10(2), 145.

Tucker, C. J. (1979). Red and photographic infrared linear combinations for monitoring vegetation. Remote Sensing of Environment, 8(2), 127-150.

Tucker, C. J., Holben, B. N., Elgin Jr, J. H., \& McMurtrey, J. E. III (1980). Relationship of spectral data to grain yield variation. Photogrammetric Engineering and Remote Sensing, 46(5), 657-666.

UBS (2020). Union Bank of Switzerland, currency exchange calculator. Retrieved June 9, 2020, from https://www.ubs.com/ch/en/cards/information/currency-converter.

Van Loon, J., Speratti, A., \& Govaerts, B. (2018). Precision for smallholder farmers: A small-scaletailored variable rate fertilizer application kit. Agriculture, 8(4), 48.

Walsh, O. S., Klatt, A. R., Solie, J. B., Godsey, C. B., \& Raun, W. R. (2013). Use of soil moisture data for refined GreenSeeker sensor based nitrogen recommendations in winter wheat (Triticum aestivum L.). Precision Agriculture, 14(3), 343-356.

Walter, A., Finger, R., Huber, R., \& Buchmann, N. (2017). Opinion: Smart farming is key to developing sustainable agriculture. Proceedings of the National Academy of Sciences, 114(24), 6148-6150.

Walter, A., Khanna, R., Lottes, P., Stachniss, C., Siegwart, R., Nieto, J., et al. (2018). Flourish-a robotic approach for automation in crop management. In Proceedings of the 14th international conference on precision agriculture (ICPA).

Wang, X., Miao, Y., Dong, R., Guan, Y., \& Mulla, D. J. (2019). Evaluating the potential benefits of fieldspecific nitrogen management of spring maize in Northeast China. In Precision agriculture'19. Proceedings of the 12th European Conference on Precision Agriculture. (pp. 877-882). Wageningen, The Netherlands: Wageningen Academic Publishers.

Wood, G. A., Taylor, J. C., \& Godwin, R. J. (2003). Calibration methodology for mapping within-field crop variability using remote sensing. Biosystems Engineering, 84(4), 409-423.

Yin, X., Beaudoin, N., Ferchaud, F., Mary, B., Strullu, L., Chlébowski, F., et al. (2020). Long-term modelling of soil $\mathrm{N}$ mineralization and $\mathrm{N}$ fate using STICS in a 34-year crop rotation experiment. Geoderma, $357,113956$.

Zebarth, B. J., Drury, C. F., Tremblay, N., \& Cambouris, A. N. (2009). Opportunities for improved fertilizer nitrogen management in production of arable crops in eastern Canada: A review. Canadian Journal of Soil Science, 89(2), 113-132.

Zha, H., Cammarano, D., Wilson, L., Li, Y., Batchelor, W. D., \& Miao, Y. (2019). Combining crop modelling and remote sensing to create yield maps for management zone delineation in small scale farming systems. In Precision agriculture'19. Proceedings of the 12th European Conference on Precision Agriculture. (pp. 671-674). Wageningen, The Netherlands: Wageningen Academic Publishers.

Zhao, B., Duan, A., Ata-Ul-Karim, S. T., Liu, Z., Chen, Z., Gong, Z., et al. (2018). Exploring new spectral bands and vegetation indices for estimating nitrogen nutrition index of summer maize. European Journal of Agronomy, 93, 113-125.

Publisher's Note Springer Nature remains neutral with regard to jurisdictional claims in published maps and institutional affiliations. 